Article

\title{
Comparative Life-Cycle Assessment of Liquefied Natural Gas and Diesel Tractor-Trailer in China
}

\author{
Shuhan $\mathrm{Hu}$ 1,3,*(D) and Hongyuan Chen ${ }^{2,4}$ (D) \\ 1 Institute of Geographic Sciences and Natural Resources Research, Chinese Academy of Sciences, \\ Beijing 100101, China \\ 2 SAIC Volkswagen Automotive Co., Ltd., Shanghai 201800, China; chenhongyuan@csvw.com \\ 3 College of Resources and Environment, University of Chinese Academy of Sciences, Beijing 100049, China \\ 4 State Key Laboratory of Advanced Design and Manufacturing for Vehicle Body, Hunan University, \\ Changsha 410082, China \\ * Correspondence: hush@igsnrr.ac.cn
}

check for updates

Citation: Hu, S.; Chen, H.

Comparative Life-Cycle Assessment of Liquefied Natural Gas and Diesel

Tractor-Trailer in China. Energies 2022, 15, 392. https://doi.org/10.3390/ en15010392

Academic Editor: Maria Cristina Cameretti

Received: 25 November 2021 Accepted: 28 December 2021

Published: 5 January 2022

Publisher's Note: MDPI stays neutral with regard to jurisdictional claims in published maps and institutional affiliations.

Copyright: (C) 2022 by the authors. Licensee MDPI, Basel, Switzerland. This article is an open access article distributed under the terms and conditions of the Creative Commons Attribution (CC BY) license (https:// creativecommons.org/licenses/by/ $4.0 /)$.
Abstract: Many countries, especially China, have extensively promoted liquefied natural gas (LNG) to replace diesel in heavy-duty vehicles for to achieve sustainable transport aims, including carbon peaks and neutrality. We developed a life-cycle calculation model for environmental load differences covering vehicle and fuel cycles to comprehensively compare the LNG tractor-trailer and its diesel counterpart in China on a full suite of environmental impacts. We found that the LNG tractortrailer consumes less aluminum but more iron and energy; emits less nitrogen oxide, sulfur oxide, nonmethane volatile organic compounds, and particulate matter but more greenhouse gases (GHG) and carbon monoxide (CO); and causes less abiotic depletion potential, acidification potential, and human toxicity potential impacts but more global warming potential (GWP) and photooxidant creation potential (POCP) impacts. Poor fuel economy was found to largely drive the higher life-cycle GHG and CO emissions and GWP and POCP impacts of the LNG tractor-trailer. Switching to the LNG tractor-trailer could reduce carbon dioxide by $52.73 \%$, GWP impact by $44.60 \%$ and POCP impact by $49.23 \%$ if it attains parity fuel economy with its diesel counterpart. Policymakers should modify the regulations on fuel tax and vehicle access, which discourage improvement in LNG engine efficiency and adopt incentive polices to develop the technologies.

Keywords: life cycle; environmental impacts; liquefied natural gas; heavy-duty vehicle; tractortrailer; China

\section{Introduction}

As the cleanest burning fossil fuel, natural gas (NG) and liquefied NG (LNG) play a significant role in alleviating oil shortages and preventing environmental degradation [1-3]. NG vehicles are also considered an important transitional type of vehicle towards the goal of carbon peak and neutralization since NG has a lower carbon content than oil [4,5]. Additionally, LNG heavy-duty vehicle (HDV) has a longer driving range and better safety [4,6-8] and reduce long-term operation costs [9-11]. Thus, LNG HDVs are regarded as a viable alternative to conventional diesel HDVs.

The number of LNG HDVs on roads in China has reached 578 thousand in 2020, with an average annual growth rate of $49.37 \%$ from 2010 to 2020 . The share of LNG HDVs in HDVs has increased from $0.15 \%$ in 2010 to $6.78 \%$ in 2020 [12,13]. Many cities in China, such as Beijing, have formulated policies that ban diesel HDVs due to their high pollutant emissions. At the same time, the promotion of LNG HDVs is encouraged by policy in some areas with abundant NG sources, such as Sichuan and Chongqing [14-16]. With the increasing use of LNG HDV as a substitute for diesel HDV in China, it is urgent to compare the environmental performance between LNG HDV and its diesel counterpart to identify 
how the expansion of LNG HDVs meets existing environmental challenges in China such as air pollution, resource shortage, and climate change.

As a practical method of assessing the environmental performance of a product system, life-cycle assessment (LCA) has been used by many researchers to quantitatively calculate the environmental changes brought by replacing internal combustion engine vehicles (ICEVs) with new energy vehicles, such as battery electric vehicles (BEVs) and fuel cell cars [5,17-22]. However, similar studies regarding NG vehicles, especially regarding LNG HDVs, are very few.

As shown in Table 1, previous studies regarding the environmental performance of LNG HDVs mainly focus on one or two types of environmental loads, such as greenhouse gas (GHG) or criteria air pollutants. There is a lack of comprehensive assessments considering a full suite of environmental impacts. Cooper et al. [23] first conducted a comparative LCA of LNG/diesel/other alternatives as fuels for heavy-duty good vehicles (HGVs) in the UK, taking the following environmental impacts into account: climate change, land use change, air quality, human health, and resource depletion. Furthermore, most studies have only considered the impacts in the usage stage or fuel cycle, i.e., well-to-wheel (WTW), and ignored the vehicle cycle covering vehicle production and end-of-life treatment. During the literature review, we found only three peer reviewed China-oriented environmental studies on LNG HDVs considering both the fuel cycle and vehicle cycle: Tu, $\mathrm{Yang}, \mathrm{Xu}$, and Chen [24]; Tu, Yang, $\mathrm{Xu}$, and Chen [25]; and Song, Ou, Yuan, Yu, and Wang [4]. In addition, the number of comparative studies on the environmental performance of Chinese LNG/conventional HDVs is still far from adequate considering the growing popularity of LNG HDVs in China.

Targeting the product with the largest share in the Chinese HDV market, the tractortrailer, this study aims to comprehensively compare the environmental performance of the LNG tractor-trailer and its diesel counterpart in China during the whole life cycle, covering both fuel cycle and vehicle cycle. The results can be used to identify the potential environmental impacts associated with switching from diesel HDV to LNG HDV in China and provide valuable information to decision-makers regarding the development of LNG HDV.

Compared to previous environmental studies on LNG HDVs, the novelty of this study includes (1) the development of a life-cycle model to quantify differences in ore material consumption, energy consumption, and air emission between the LNG tractor-trailer and its diesel counterpart covering both vehicle cycle and fuel cycle, and (2) the comprehensive consideration of a full suite of environmental impacts related to resource depletion, air quality, and climate change, which could provide a more holistic view of the trade-offs associated with switching from diesel to LNG tractor-trailers in China.

Table 1. Previous studies regarding the environmental performance of LNG HDVs.

\begin{tabular}{|c|c|c|c|c|}
\hline Authors & Vehicle Type & $\begin{array}{l}\text { Country/ } \\
\text { Region }\end{array}$ & Research Boundary & $\begin{array}{c}\text { Assessed } \\
\text { Environmental } \\
\text { Loads/Impacts }\end{array}$ \\
\hline Arteconi, et al. [26] & $\begin{array}{l}\text { HGVs powered by diesel, LNG } \\
\text { under two procurement } \\
\text { scenarios (the regasification } \\
\text { terminal or producing LNG } \\
\text { locally with small-scale plants) }\end{array}$ & EU-15 (i) & Fuel cycle & GHG emissions \\
\hline $\begin{array}{l}\text { Tong, Jaramillo, } \\
\text { and Azevedo [27] }\end{array}$ & $\begin{array}{l}7 \text { types of medium- and } \\
\text { heavy-duty vehicles powered } \\
\text { by conventional gas, diesel, } \\
\text { and NG-based fuels }\end{array}$ & U.S. & Fuel cycle & GHG emissions \\
\hline $\begin{array}{l}\text { Tu, Yang, Xu, and } \\
\text { Chen [25] }\end{array}$ & LNG and diesel mixer & China & $\begin{array}{c}\text { Fuel cycle }+ \text { vehicle } \\
\text { cycle }\end{array}$ & $\begin{array}{l}\text { GHG and criteria air } \\
\text { pollutant emissions }\end{array}$ \\
\hline
\end{tabular}


Table 1. Cont.

\begin{tabular}{|c|c|c|c|c|}
\hline Authors & Vehicle Type & $\begin{array}{l}\text { Country/ } \\
\text { Region }\end{array}$ & Research Boundary & $\begin{array}{c}\text { Assessed } \\
\text { Environmental } \\
\text { Loads/Impacts }\end{array}$ \\
\hline $\begin{array}{l}\mathrm{Tu}, \mathrm{Xu}, \mathrm{Chen} \text {, and } \\
\text { Yang [24] }\end{array}$ & LNG and diesel mixer & China & $\begin{array}{l}\text { Fuel cycle + vehicle } \\
\text { cycle }\end{array}$ & Energy consumption \\
\hline Cai, et al. [28] & $\begin{array}{l}\text { LNG combination short-haul } \\
\text { truck, compressed natural gas } \\
\text { (CNG) transit bus, CNG refuse } \\
\text { truck and their diesel } \\
\text { counterparts }\end{array}$ & U.S. & Fuel cycle & $\begin{array}{c}\text { Freshwater } \\
\text { consumption, } \mathrm{GHG} \\
\text { emissions, } \mathrm{NO}_{\mathrm{x}} \text { and } \\
\text { PM emissions }\end{array}$ \\
\hline $\begin{array}{l}\text { Song, Ou, Yuan, Yu, } \\
\text { and Wang [4] }\end{array}$ & $\begin{array}{l}\text { LNG and diesel HDVs (tractor, } \\
\text { dump, freight, and special truck) }\end{array}$ & China & $\begin{array}{l}\text { Fuel cycle + vehicle } \\
\text { cycle }\end{array}$ & $\begin{array}{l}\text { Energy consumption } \\
\text { and GHG emissions }\end{array}$ \\
\hline Ozbilen, et al. [29] & $\begin{array}{c}\text { Class } 8 \text { trucks powered by LNG, } \\
\text { CNG, Euro IV diesel, Biodiesel, } \\
\text { Fisher-Tropsch diesel }\end{array}$ & Canada & $\begin{array}{l}\text { Vehicle cycle + Operation } \\
\text { stage + road cycle }\end{array}$ & $\begin{array}{l}\text { Global warming } \\
\text { potential (GWP) }\end{array}$ \\
\hline $\begin{array}{l}\text { Cooper, Hawkes, } \\
\text { and Balcombe [23] }\end{array}$ & $\begin{array}{l}\text { HGVs powered by CNG, LNG } \\
\text { (dedicated and dual fuel), } \\
\text { diesel, biodiesel, dimethyl } \\
\text { ether, and electric battery }\end{array}$ & U.K. & Fuel cycle & $\begin{array}{l}\text { GWP, land use change, } \\
\text { particulate matter and } \\
\text { photochemical ozone } \\
\text { formation potential, } \\
\text { human toxicity } \\
\text { potential and metals } \\
\text { depletion, and fossil } \\
\text { fuel depletion potential }\end{array}$ \\
\hline $\begin{array}{l}\text { Langshaw, } \\
\text { et al. [30] }\end{array}$ & $\begin{array}{l}\text { LNG and diesel } \\
\text { long-haul HGVs }\end{array}$ & U.K. & Fuel cycle & GHG emissions \\
\hline $\begin{array}{l}\text { Yuan, Ou, Peng, } \\
\text { and Yan [5] }\end{array}$ & $\begin{array}{l}\text { CNG, LNG and diesel transit } \\
\text { buses with 12.5-14.5 ton and } \\
\text { heavy-duty truck with } 20-25 \text { ton }\end{array}$ & China & Fuel cycle & GHG emissions \\
\hline
\end{tabular}

Note: (i) Fifteen member states of Europe, including Austria, Belgium, Denmark, Finland, France, Germany, Greece, Ireland, Italy, Luxembourg, The Netherlands, Portugal, Spain, Sweden, and the United Kingdom.

\section{Materials and Methods}

\subsection{Goal and Scope Definition}

The goal of this study is to provide a comparative LCA of a representative LNG tractortrailer and its diesel counterpart. Thus, the system boundary covers all the processes related to the main differences between the two alternatives from a life-cycle perspective. The processes in which no or negligible differences exist are excluded. It is generally regarded that there is no difference between the two alternatives during vehicle assembly, so the process of vehicle assembly is not taken into account in this study. The differences in energy consumption and environmental emissions during end-of-life treatment of the two alternative HDVs are negligible, so this study only considers recycled materials in the stage of recycling.

The main differences in environmental impacts between the two alternatives are associated with their different fuel uses and congeneric accessories, which differ in material composition. Therefore, the scope of this study includes vehicle operation (i.e., "tank-towheel", TTW), fuel production (i.e., "well-to-tank", WTT), accessory production (covering ore material acquisition, material preparation and accessory manufacturing), and recycling. Figure 1 shows the system boundary and processes of the system under study. 


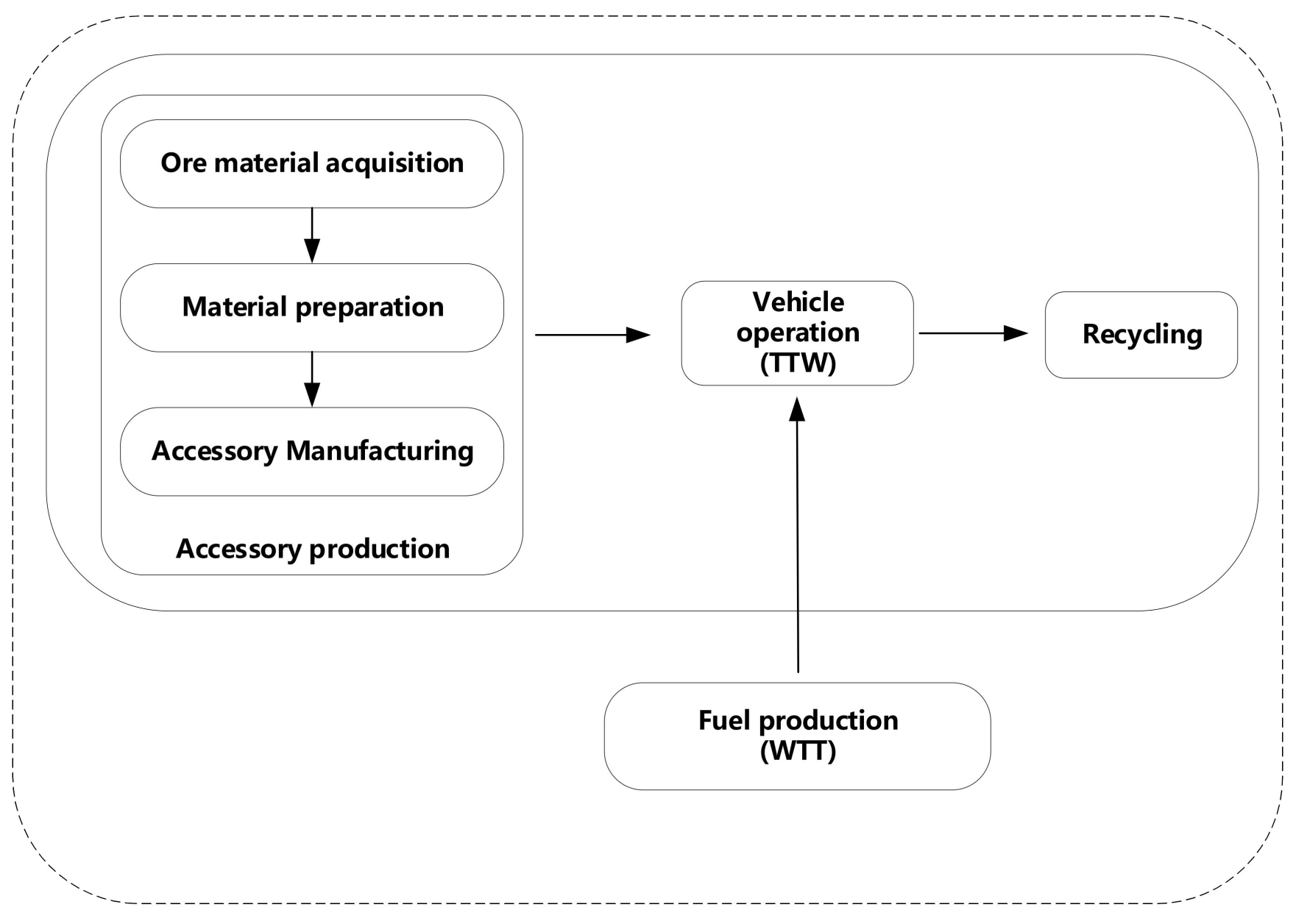

Figure 1. System boundary of this study.

In this study, we used a tractor-trailer with a tractive weight of 40 tons and a lifetime of 400,000 km under average Chinese conditions as a functional unit. To ensure the comparability of our case vehicles, we adopted the following criteria for selection of specific models: (1) the two alternatives should be the same class with similar boundary dimensions and curb weights; (2) the two alternatives should be representative models with their respective powertrain at the leading level of their class, and the power ratings of their engines should be similar; (3) excluding powertrains, the differences between other vehicle structures should be as small as possible; and (4) both types of vehicles should have similar driving experience, dynamic property, comfortability, and safety.

Following these criteria, this study selected an LNG tractor-trailer (HN4250NGX41C9M5) and its diesel counterpart (HN4250H40C4M5) manufactured in 2017 by Hualing Xingma Automobile (Group) Co. Ltd. (CAMC) in Anhui Province of China as the representative model (see Figure 2) since CAMC is one of the primary HDV manufacturers in China. The details on their specification are listed in Table A1.

\subsection{Life-Cycle Inventory (LCI) Analysis}

Based on the previous studies of Hunan University [24,25,31], this study developed an LCI model for quantitatively comparing the difference in environmental loads between the LNG HDV and its diesel counterpart in a life cycle considering vehicle cycle and fuel cycle, which considers not only the differences in energy consumption and air emission but also ore material consumption. We compiled the model by MATLAB software to obtain the results. 


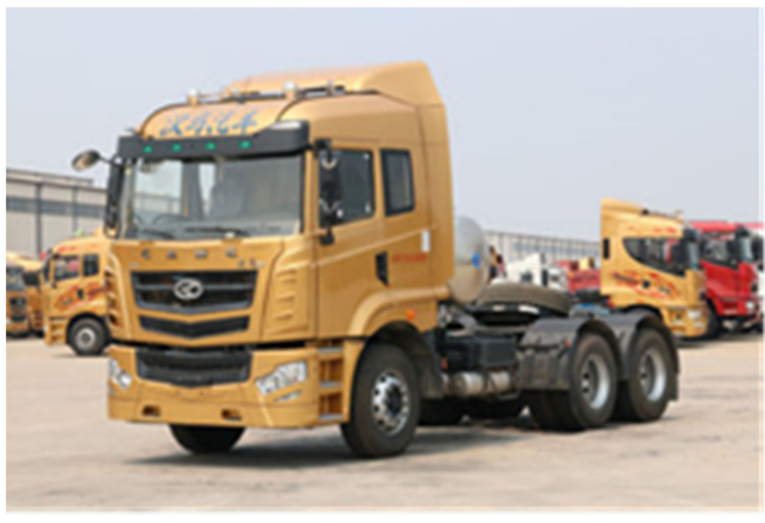

(a)

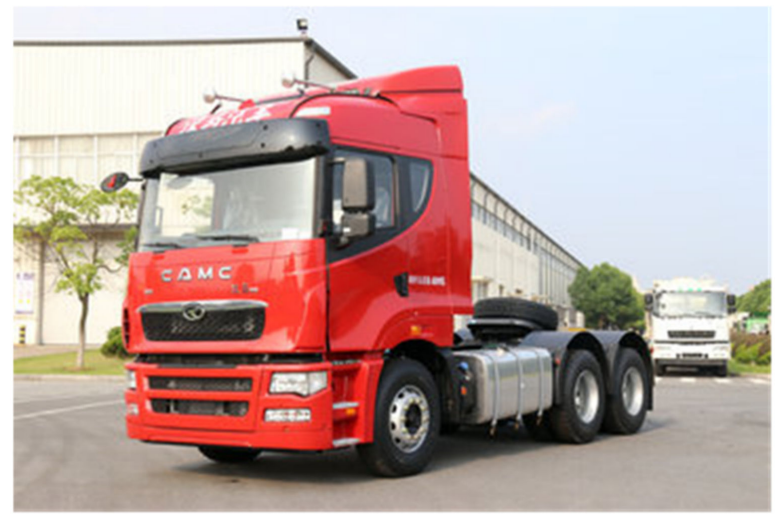

(b)

Figure 2. The selected tractor-trailers for comparison: (a) LNG tractor-trailer (HN4250NGX41C9M5); (b) Diesel tractor-trailer (HN4250H40C4M5).

\subsubsection{Model for Differences in Environmental Loads}

1. Matrix for mass difference of accessory materials

The difference in mass of accessory materials leads to the difference in ore material consumption, energy consumption and air emission during ore material acquisition and preparation between the two alternative vehicles. Thus, we first established a matrix for the mass difference $(M D)$ of accessory materials (see Equation (1)):

$$
\mathbf{M D}_{\boldsymbol{a}}=\left(m l_{a_{i j}}\right)_{k \times n}-\left(m c_{a_{i j}}\right)_{k \times n}
$$

where $m l_{a_{i j}}(\mathrm{~kg})$ and $m c_{a_{i j}}(\mathrm{~kg})$ represent, for LNG HDV and its diesel counterpart, respectively, the mass of material $j$ used in accessory $i, k$ denotes the number of types of accessories that differ in material composition between the two alternatives, and $n$ represents the number of total material types used in these accessories. If the number of material types used in accessory $j$ of a certain HDV is less than $n$, the vacant elements are replaced with 0.

2. Calculation of ore material consumption difference

Assuming that all of the materials used in HDVs come from raw ore, the matrix for life-cycle difference in ore material $j$ consumption can be established as Equation (2):

$$
\boldsymbol{M D}_{\boldsymbol{o}}=\boldsymbol{M D}_{\boldsymbol{a}} \times\left(\boldsymbol{I}_{\boldsymbol{n}}-\boldsymbol{\eta}_{r}\right) \times \boldsymbol{\eta}_{p}^{-1} \times \boldsymbol{\eta}_{m}^{-1}=\left(m d_{o_{i j}}\right)_{k \times n}
$$

where $\boldsymbol{\eta}_{p}, \boldsymbol{\eta}_{m}$ and $\boldsymbol{\eta}_{r}$ respectively represents the $n$ order diagonal matrix for the material use ratio during ore material preparation, et. $\eta_{p}=\operatorname{diag}\left(\eta_{p_{1}}, \cdots, \eta_{p_{j}}, \cdots, \eta_{p_{n}}\right)$, and the material use ratio during accessory manufacture, et. $\eta_{m}=\operatorname{diag}\left(\eta_{m_{1}}, \cdots, \eta_{m_{j}}, \cdots, \eta_{m_{n}}\right)$, the material recovery rate during vehicle recycling, et. $\eta_{r}=\operatorname{diag}\left(\eta_{r_{1}}, \cdots, \eta_{r_{j}}, \cdots, \eta_{r_{n}}\right), \eta_{p_{j}}$, $\eta_{m_{j}}$ and $\eta_{r_{j}}$ respectively denote the use ratio during acquisition and preparation, the use ratio during manufacturing and assembly, and the recovery ratio during vehicle recycling for material $j . m d_{o_{i j}}(\mathrm{~kg})$ represents the difference in ore material $j$ consumption for accessory $i$ between the two alternatives.

Accordingly, the life-cycle difference in ore material $j$ consumption can be calculated as Equation (3).

$$
m d_{o j}=\sum_{i=1}^{k} m d_{o_{i j}}
$$

3. Calculation of the difference in energy consumption and air emission 
The difference in energy consumption and air emission between LNG and diesel HDVs is derived from their differences in material and fuel use as well as the manufacturing process of similar accessories, which is related to the following stages: ore material acquisition, material preparation, accessory manufacture, vehicle operation (TTW), and fuel production (WTT).

First, matrices for the difference in energy consumption and air emission during ore material acquisition and preparation are respectively established as given in Equations (4) and (5).

$$
\begin{gathered}
\boldsymbol{E D}_{b}=\left(\boldsymbol{M D}_{\boldsymbol{a}} \times \boldsymbol{\eta}_{p}^{-1} \times \boldsymbol{\eta}_{\boldsymbol{m}}^{-1}\right) \times\left(e_{o_{j x}}\right)_{n \times s_{b}}+\left(\boldsymbol{M D}_{\boldsymbol{a}} \times \boldsymbol{\eta}_{\boldsymbol{m}}^{-1}\right) \times\left(e_{p_{j x}}\right)_{n \times s_{b}}=\left(e d_{b_{i x}}\right)_{k \times s_{b}} \\
\boldsymbol{P D}_{b}=\left(\boldsymbol{M} \boldsymbol{D}_{\boldsymbol{a}} \times \boldsymbol{\eta}_{p}^{-1} \times \boldsymbol{\eta}_{\boldsymbol{m}}^{-1}\right) \times\left(p_{o_{j y}}\right)_{n \times t}+\left(\boldsymbol{M} \boldsymbol{D}_{\boldsymbol{a}} \times \boldsymbol{\eta}_{\boldsymbol{m}}^{-1}\right) \times\left(p_{p_{j y}}\right)_{n \times t}=\left(p d_{b_{i y}}\right)_{k \times t}
\end{gathered}
$$

where $\boldsymbol{M} \boldsymbol{D}_{\boldsymbol{a}} \times \boldsymbol{\eta}_{p}^{-1} \times \boldsymbol{\eta}_{m}^{-1}(\mathrm{~kg})$ and $\boldsymbol{M} \boldsymbol{D}_{\boldsymbol{a}} \times \boldsymbol{\eta}_{m}^{-1}(\mathrm{~kg})$ represent the matrix for mass difference of ore materials acquired for preparation and materials prepared for accessory manufacture, respectively; $e_{o_{j x}}(\mathrm{kgce} / \mathrm{kg})$ and $e_{p_{j x}}(\mathrm{kgce} / \mathrm{kg})$ denote the intensity of energy $x$ for acquiring and preparing material $j$, respectively; $p_{o_{j y}}(\mathrm{~kg} / \mathrm{kg})$ and $p_{p_{j y}}(\mathrm{~kg} / \mathrm{kg})$ denote the intensity of air emission $y$ for acquiring and preparing material $j$, respectively; $e d_{b_{i x}}(\mathrm{kgce})$ and $p d_{b_{i y}}(\mathrm{~kg})$ represent the amount difference in energy $x$ consumption and air emission $y$ for acquiring and preparing materials to manufacture accessory $i$, respectively; and $s_{b}$ and $t$ denote the number of total energy types and total emission types related to ore material acquisition and material preparation, respectively. If the number of energy types for acquiring and preparing material $j$ or emission types for acquiring and preparing material $j$ is less than $s_{b}$ or $t$, the vacant elements are replaced with 0 . When there are no respective data on energy or emission intensity during the two stages, the integrated data for the two stages $\left(e_{0+p_{j x}}\right.$ or $p_{o+p_{j y}}$ ) can be used for the calculation as given in Equation (6) or Equation (7).

$$
\begin{aligned}
& \boldsymbol{E D}_{b}=\left(\boldsymbol{M D}_{\boldsymbol{a}} \times \boldsymbol{\eta}_{\boldsymbol{m}}^{-1}\right) \times\left(e_{o+p_{j x}}\right)_{n \times s_{b}}=\left(e d_{b_{i x}}\right)_{k \times s_{b}} \\
& \boldsymbol{P D}_{b}=\left(\boldsymbol{M D}_{\boldsymbol{a}} \times \boldsymbol{\eta}_{\boldsymbol{m}}^{-1}\right) \times\left(p_{o+p_{j y}}\right)_{n \times t}=\left(p d_{b_{i y}}\right)_{k \times t}
\end{aligned}
$$

where $e_{o+p_{j x}}=\eta_{p_{j}}{ }^{-1} \times e_{o_{j x}}+e_{p_{j x}}$ and $p_{o+p_{j y}}=\eta_{p_{j}}{ }^{-1} \times p_{o_{j y}}+p_{p_{j y}}$.

Then, the life-cycle differences in energy consumption and air emission $y$ are calculated respectively by Equations (8) and (9).

$$
\begin{aligned}
& e d=\underbrace{\sum_{i=1}^{k} \sum_{x=1}^{s_{b}} e d_{b_{i x}}}+\underbrace{\sum_{i=1}^{k} \sum_{x=1}^{s_{m}} e d_{m_{i x}}} \\
& +\underbrace{D \times\left(e l_{0}-e c_{0}\right)}_{\begin{array}{c}
\text { Energy consumption difference } \\
\text { during vehicle operation }
\end{array}} \\
& +\underbrace{D \times \sum_{x=1}^{s_{u}}\left(e l_{0} \times e l_{u x}-e c_{o} \times e c_{u x}\right)}_{\begin{array}{c}
\text { Energy consumption difference } \\
\text { during fuel production }
\end{array}}
\end{aligned}
$$




$$
\begin{aligned}
& p d_{y}=\underbrace{\sum_{i=1}^{k} p d_{b_{i y}}}+\underbrace{\sum_{i=1}^{k} p d_{m_{i y}}} \\
& \text { Air emission difference } \\
& \text { during ore material acquisition during manufacturing accesories } \\
& \text { and preparation } \\
& +\underbrace{D \times\left(p l_{o y}-p c_{o y}\right)}_{\text {Air emission difference }}+\underbrace{D \times\left(e l_{o} \times p l_{u y}-e c_{o} \times p c_{u y}\right)}_{\text {Air emission difference }} \\
& \text { during vehicle operation during fuel production }
\end{aligned}
$$

where $e d_{m_{i x}}(\mathrm{kgce})$ and $p d_{m i y}(\mathrm{~kg})$ represent the amount difference in energy $x$ consumption and air emission $y$ for manufacturing accessory $i$ between the two alternatives, $D$ represents the total distance travelled during the vehicle lifetime $(100 \mathrm{~km}), e l_{o}(\mathrm{kgce} / 100 \mathrm{~km})$ and $e c_{o}$ $(\mathrm{kgce} / 100 \mathrm{~km})$ represent the amount of LNG and diesel consumption per unit distance, respectively; $p l_{o y}(\mathrm{~kg} / 100 \mathrm{~km})$ and $p c_{o y}(\mathrm{~kg} / 100 \mathrm{~km})$ denote the amount of air emission $y$ for travelling a unit distance by LNG HDV and its diesel counterpart, respectively; $e l_{u x}$ (kgce/kgce) and $e c_{u x}$ (kgce/kgce) denote the amount of energy $x$ consumption for producing a unit of LNG and diesel, respectively; $p l_{u y}(\mathrm{~kg} / \mathrm{kgce})$ and $p c_{u y}(\mathrm{kgce} / \mathrm{kgce})$ denote the amount of emission $y$ for producing a unit of LNG and diesel, respectively; and $s_{m}$ and $s_{u}$ represent the number of total energy types related to accessory manufacturing and producing a unit of LNG or diesel, respectively. If the number of energy types for producing a certain accessory or producing a unit of a certain fuel is less than $s_{m}$ or $s_{u}$, the vacant elements are replaced with 0.

\subsubsection{Data and Assumption}

According to the model established above, we first identified the accessories that differ in material composition and obtained the data on their material composition by field survey on CAMC. The details are shown in Table 2.

Table 2. The differences in accessory materials between the two alternative tractor-trailers.

\begin{tabular}{cccc}
\hline & Material Types & \multicolumn{2}{c}{ Mass (kg) } \\
\cline { 3 - 4 } Vehicle and Accessory Types & & Steel & Al-Mg Alloy \\
\hline LNG tractor-trailer & Fuel tank (LNG cylinder) & 510 & 0 \\
(HN4250NGX41C9M5) & Bracket & 142 & 0 \\
Diesel tractor-trailer & Fuel tank (diesel tank) & 0 & 46 \\
(HN4250H40C4M5) & Bracket & 39 & 0 \\
\hline
\end{tabular}

Data source: CAMC.

Based on the identification of accessory materials, we collected other data for use in the model, including use ratios and recovery ratios, energy, and air emission intensities in different life-cycle stages.

To keep the data as consistent as possible, we acquired the data during ore material acquisition, material preparation, and diesel production from one database named SinoCenter [32] for the material and energy life-cycle inventory in China since most production occurs in China. According to the Chinese Bureau of Statistics, the production of steel in China was higher than the sales, and cast aluminum production and sales occurred in similar amounts in 2018; diesel imports only account for $0.04 \%$ of Chinese diesel consumption in 2018. In addition, the data on Al-Mg alloy were assumed to equal those of cast aluminum due to the data availability. We adopted data on the energy and air emission intensity during diesel production from GREET 2020 [33], which was developed for the US, as most LNG in China is imported from overseas and the US is one of China's importers. The data on the energy intensities during accessory manufacturing were obtained through Tu, Yang, $\mathrm{Xu}$, and Chen's study [24] and the SinoCenter database. Tu, Yang, Xu, and Chen's study [24] provides the amount of direct energy consumption for manufacturing the fuel tank and 
bracket of a diesel HDV and its LNG counterpart in China in coal equivalent, which was converted to electricity by the conversion factor. SinoCenter provides the average amount of coal, crude oil, and NG consumption for producing $1 \mathrm{~kW} \cdot \mathrm{h}$ electricity in China. We multiplied the two together to obtain the amount of coal, crude oil, and NG consumption for manufacturing the fuel tank and bracket of a diesel HDV and its LNG counterpart. As the manufacturing processes of the metal fuel tank and bracket mainly cover stamping and welding, the direct emissions during this phase are negligible and excluded from this calculation. Regarding the air emissions during vehicle operation, NMVOC, CO, PM, and $\mathrm{CH}_{4}$ emissions were directly collected from the enterprise, while $\mathrm{SO}_{\mathrm{x}}$ and $\mathrm{CO}_{2}$ emissions were obtained through external sources. $\mathrm{CO}_{2}$ emissions during vehicle operation were calculated by the amount of fuel consumption, calorific value and $\mathrm{CO}_{2}$ emission factor of fuel provided by the IPCC. Based on the method in the "Technical Guidelines for Compiling Air Pollutant Emission Inventory of On-Road Vehicles (Trial)" [34], issued by the Ministry of Ecology and Environment of the People's Republic of China (formerly Ministry of Environmental Protection of the People's Republic of China) in December 2014, SOx emissions during vehicle operation were calculated by the amount of fuel consumption and sulfur contents of fuel, which can be acquired according to the regulations on oil product standards.

The details on the data sources are shown in Table 3, and the specific inventories are listed in Table A2.

Table 3. Data sources of inventory data for different life-cycle stages.

\begin{tabular}{|c|c|c|}
\hline Life-Cycle Stage & Data Types & Data Source \\
\hline \multirow{3}{*}{$\begin{array}{l}\text { Ore material acquisition } \\
\text { and material preparation }\end{array}$} & $\begin{array}{l}\text { Use ratios during ore material acquisition and material } \\
\text { preparation for steel }{ }^{(\mathrm{i})} \text { and cast aluminum }{ }^{\text {(i) }}\end{array}$ & SinoCenter [32] \\
\hline & $\begin{array}{l}\text { Integrated energy intensity data on coal, crude oil, and NG for } \\
\text { acquiring and preparing steel }{ }^{(\mathrm{i})} \text { and cast aluminum (ii) }\end{array}$ & SinoCenter [32] \\
\hline & $\begin{array}{l}\text { Integrated emission intensity data on } \mathrm{NMVOC}, \mathrm{SO}_{\mathrm{x}}, \mathrm{NO}_{\mathrm{x}}, \mathrm{CO}, \\
\mathrm{CO}_{2}, \mathrm{PM} \text { and } \mathrm{CH}_{4} \text { for acquiring and preparing steel }{ }^{(\mathrm{i})} \text { and cast } \\
\text { aluminum }\end{array}$ & SinoCenter [32] \\
\hline \multirow{4}{*}{ Accessory manufacture } & $\begin{array}{l}\text { Use ratios of steel and cat aluminum during } \\
\text { accessory manufacture }\end{array}$ & WorldAutoSteel (2017) [35] \\
\hline & $\begin{array}{l}\text { Amount of direct energy consumption for manufacturing fuel } \\
\text { tank and bracket in coal equivalent }\end{array}$ & Tu, Yang, Xu and Chen (2013) [24] \\
\hline & Conversion factor from electricity to coal equivalent & China Energy Statistical Yearbook 2019 [36] \\
\hline & $\begin{array}{l}\text { Amount of coal, Crude oil, and NG consumption for producing } \\
\qquad 1 \mathrm{~kW} \cdot \mathrm{h} \text { electricity }\end{array}$ & SinoCenter [32] \\
\hline Recycling & Recovery ratio of steel and aluminum & WorldAutoSteel (2017) [35] \\
\hline \multirow{4}{*}{ Fuel production } & $\begin{array}{l}\text { Amount of coal, crude oil, and NG consumption for producing } \\
\qquad \text { a unit of LNG }{ }^{\text {(iii) }}\end{array}$ & GREET 2020 [33] \\
\hline & $\begin{array}{l}\text { Amount of NMVOC, } \mathrm{SO}_{x}, \mathrm{NO}_{x}, \mathrm{CO}, \mathrm{CO}_{2}, \mathrm{PM} \text {, and } \mathrm{CH}_{4} \\
\text { emissions for producing a unit of } \mathrm{LNG} \text { (iii) }\end{array}$ & GREET 2020 [33] \\
\hline & $\begin{array}{l}\text { Amount of coal, crude oil, and NG consumption for producing } \\
\qquad \text { a unit of diesel }^{\text {(iv) }}\end{array}$ & SinoCenter [32] \\
\hline & $\begin{array}{l}\text { Amount of NMVOC, } \mathrm{SO}_{x}, \mathrm{NO}_{x}, \mathrm{CO}, \mathrm{CO}_{2}, \mathrm{PM} \text {, and } \mathrm{CH}_{4} \\
\text { emissions for producing a unit of diesel (iv) }\end{array}$ & SinoCenter [32] \\
\hline \multirow{4}{*}{ Vehicle operation } & Amount of LNG and diesel consumption per unit distance & CAMC \\
\hline & $\begin{array}{c}\text { Amount of } \mathrm{NMVOC}^{(\mathrm{v})}, \mathrm{NO}_{x}, \mathrm{CO}, \mathrm{CO}_{2}, \mathrm{PM} \text {, and } \mathrm{CH}_{4} \text { emission } \\
\text { per unit work for operating } \mathrm{LNG} \text { tractor-trailer and its } \\
\text { diesel counterpart }\end{array}$ & $\begin{array}{c}\text { CAMC (tested by National Motor Vehicle Quality } \\
\text { Supervision and Inspection Center through ESC } \\
\text { and ELR experiments) }\end{array}$ \\
\hline & Sulfur in diesel fuel (vi) & GB 19147-2016 [37] \\
\hline & $\mathrm{CO}_{2}$ emission factor of natural gas and diesel & IPCC 2006 [38] \\
\hline
\end{tabular}


Table 3. Cont.

\begin{tabular}{|c|c|c|}
\hline Life-Cycle Stage & Data Types & Data Source \\
\hline & $\begin{array}{l}\text { Conversion factor from heat and electricity to coal equivalent } \\
\text { and calorific value of diesel }\end{array}$ & China Energy Statistical Yearbook 2019 [36] \\
\hline & Calorific value of LNG and diesel density & BP Statistical Review of World Energy 2020 [39] \\
\hline & LNG density & $\begin{array}{c}\text { https: / / www.unitrove.com/engineering/gas- } \\
\text { technology/liquefied-natural-gas } \\
\text { (15 October 2021) }\end{array}$ \\
\hline
\end{tabular}

Note: (i) The system boundary covers iron ore mining, iron ore dressing, sintering and ironmaking (BF), steelmaking (BOF, EAF), the main process during material primary rolling, production of related auxiliary materials (metallurgical lime, metallurgical coke, ferrosilicate) and main raw materials (ore, coal, etc.) transport but excludes production equipment manufacturing and infrastructure (e.g., plant) construction. The time boundary is 2014 for material and 2017 for energy. The technical level is China's average level for the BF-BOF process and EAF process. All data are from enterprise surveys. ${ }^{\text {(ii) }}$ The system boundary is from cradle to gate (products). Chinese typical aluminum production processes including mining bauxite, alumina production, cryolite molten salt electrolysis of alumina, electrolytic aluminum liquid purified (subtraction) and casting aluminum ingots, auxiliary materials (prebaked anode or self-baking carbon anode paste) production, transport of the main materials, and aluminum alloy production and forging, but excluding production equipment manufacturing and infrastructure construction. The time boundary is 2014 for material and 2017 for energy. The technical level is China's average level for mixed alumina-electrolysis. The data are from enterprise surveys, literature, and statistical yearbooks. (iii) The system boundary covers natural gas exploitation, processing, and transportation and takes into account the interaction and influence of various types of energy production but excludes production equipment manufacturing and infrastructure construction. The time boundary is 2017. The technical level is China's average level. The data are from enterprise surveys, literature, and statistical yearbooks. (iv) The system boundary covers crude oil exploitation, processing, and transportation and takes into account the interaction and influence of various types of energy production but excludes production equipment manufacturing and infrastructure construction. The time boundary is 2017. The technical level is China's average level. The data are from enterprise surveys, literature, and statistical yearbooks. (v) The test item for the LNG tractor-trailer is NMHC and HC for the diesel tractor-trailer, and NMVOC is primarily composed of HC. This study used the amounts of NMHC and HC to represent the amount of NMVOCs to remain consistent with other life-cycle stages. (vi) According to the latest Chinese national standard for automobile diesel fuels (GB 19147-2016), the sulfur limit in diesel fuel was set to $10 \mathrm{mg} / \mathrm{kg}$ to meet the China V emission standard. Due to the data availability, this study used the limit of $10 \mathrm{mg} / \mathrm{kg}$ as the value on sulfur in HDV diesel fuel.

\subsection{Life-Cycle Impact Assessment (LCIA)}

This study used the CML 2001 model at the midpoint level for classification and characterization. The CML 2001 model has been extensively adopted to assess the environmental impacts of resource consumption and environmental emissions in China since the indicators in this model were considered to represent Chinese environmental problems well $[31,40,41]$.

The characterization process formula is defined by Equation (10) [42].

$$
I S_{i}=\sum_{j} E F_{i j} \times A M T_{i j}
$$

where $I S_{i}$ denotes the potential of the impact category $i, E F_{i j}$ denotes the characterization factor for substance $j$ that contributes to the impact category $i$, and $A M T_{i j}$ denotes the quantity of substance $j$ that contributes to the impact category $i$.

The environmental loads identified in the LCI were sorted with regard to five relevant CML 2001 impact categories: abiotic depletion potential (ADP), global warming potential (GWP 100), acidification potential (AP), human toxicity potential (HTP), and photooxidant creation potential (POCP). These impacts indicate actual environmental problems occurring in China, such as air pollution, resource shortages, and climate change. The description, units, and main contributors of impact categories considered in this study are shown in Table 4. We used the latest characterization factors of ADP available for China calculated by Zhang, Feng, and Wang (2016) [43] and adopted other factors from Oers (2015) [44] due to data availability. The details on the characterization factors are shown in Table A3. 
Table 4. The description, units, and main contributors of CML 2001 impact categories.

\begin{tabular}{|c|c|c|c|}
\hline Impact Category & Description & Unit & Main Contributors \\
\hline ADP & Resource depletion & kg antimony eq. & $\begin{array}{l}\text { Diesel, NG, Iron ore, } \\
\text { Aluminum ore }\end{array}$ \\
\hline GWP 100 & $\begin{array}{c}\text { Climate change } \\
\text { within a time horizon } \\
\text { of } 100 \text { years }\end{array}$ & $\mathrm{kg} \mathrm{CO}_{2}$ eq. & $\mathrm{CO}_{2}, \mathrm{~N}_{2} \mathrm{O}, \mathrm{CH}_{4}$ \\
\hline $\mathrm{AP}$ & $\begin{array}{l}\text { Environmental } \\
\text { deterioration: acid } \\
\text { rain corrosion }\end{array}$ & $\mathrm{kg} \mathrm{SO}_{2}$ eq. & $\mathrm{SO}_{\mathrm{x}}, \mathrm{NO}_{\mathrm{x}}$ \\
\hline HTP & Health damage & $\begin{array}{c}\mathrm{kg} \\
\text { 1,4-dichlorobenzene } \\
\text { eq. }\end{array}$ & $\mathrm{SO}_{\mathrm{x}}, \mathrm{NO}_{\mathrm{x}}, \mathrm{PM}$ \\
\hline POCP & $\begin{array}{c}\text { Environmental } \\
\text { deterioration: } \\
\text { photochemical smog } \\
\text { pollution }\end{array}$ & $\mathrm{kg} \mathrm{C}_{2} \mathrm{H}_{4}$ eq. & $\begin{array}{c}\mathrm{SO}_{x}, \mathrm{CO}, \mathrm{NMVOC}, \\
\mathrm{CH}_{4}\end{array}$ \\
\hline
\end{tabular}

\subsection{Sensitivity Analysis}

Fuel tank (gas cylinder and oil tank) and engine are two prominent differences between LNG and diesel HDVs. Currently, the technologies of gas cylinders and oil tanks are very mature; however, there is still plenty of room for improvement of engine technology. With the continuous progress and maturity of gas engine technology, equivalence ratio combustion, blending combustion, dual fuel combustion, and high-pressure direct injection will be increasingly applied to engines in the near future. However, the above assessment was conducted based on the current level of engine technology and does not consider the development of engine technology. We selected the fuel consumption rates of LNG and diesel tractor-trailer $(\mathrm{L} / 100 \mathrm{~km})$ to reflect the level of engine technology for the sensitivity analysis. The higher fuel the consumption rate, the worse the fuel economy and vice versa. The development of engine technology alone can lead to a $30 \%$ reduction in fuel consumption [45]. The two factors are thus reduced by $30 \%$ to examine the influence of that factor on the five categories of environmental impacts.

\section{Results and Discussion}

\subsection{LCI Results}

\subsubsection{Resource Consumption}

The ore material consumption differences between the two alternatives result from the differences in material composition and mass of their fuel tanks and brackets. As shown in Figure 3a, the LNG tractor trailer consumes $227.85 \mathrm{~kg}$ more iron ore and $47.37 \mathrm{~kg}$ less aluminum ore than its diesel counterpart. This is because the LNG cylinder is made of steel, while the diesel tank is made of Al-Mg alloy. 


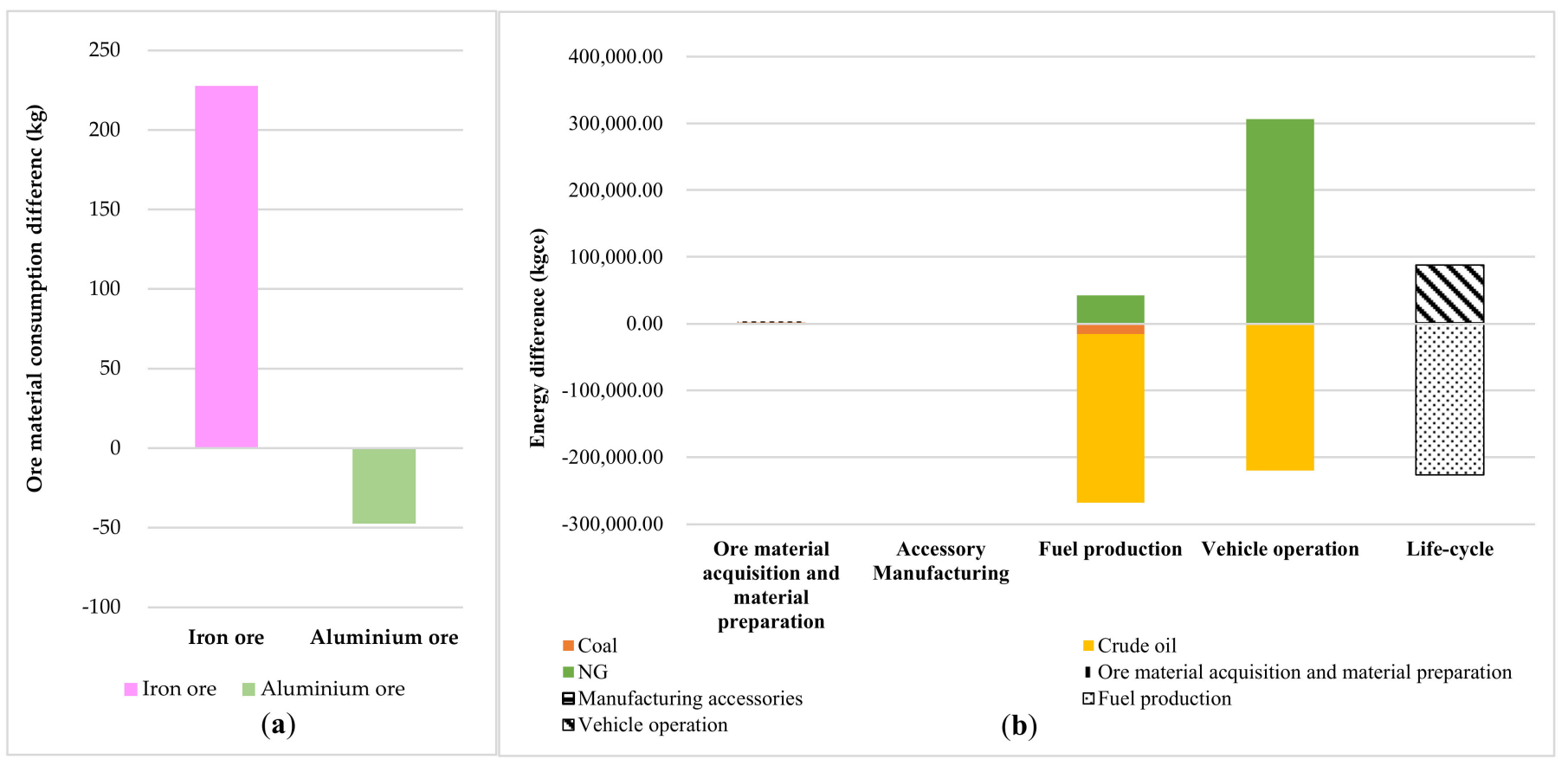

Figure 3. Resource consumption of the LNG tractor-trailer compared to the diesel tractor-trailer: (a) ore material; (b) energy.

As shown in Figure $3 \mathrm{~b}$ and Table 5, the life-cycle energy consumption of the LNG tractor-trailer is $138,215.61$ kgce lower than that of its diesel counterpart. This result is predominantly caused by the and fuel production stage (71.96\%). The energy consumption for operating the LNG tractor-trailer is $86,538.02 \mathrm{kgce}$ higher than that for operating its diesel counterpart, while the energy consumption for producing LNG of the LNG tractortrailer is 226,132.93 kgce lower than that for producing the diesel of its diesel counterpart. The increase in energy consumption of the LNG tractor-trailer during operation is far less than the reduction in its energy consumption during fuel production. The lower life-cycle energy consumption of the LNG tractor-trailer is mainly due to its much lower crude oil consumption for producing LNG.

Table 5. Energy consumption of the LNG tractor-trailer compared to the diesel tractor-trailer.

\begin{tabular}{cccccc}
\hline Processes & $\begin{array}{c}\text { Ore Material Acquisition } \\
\text { and Material Preparation }\end{array}$ & $\begin{array}{c}\text { Accessory } \\
\text { Manufacturing }\end{array}$ & $\begin{array}{c}\text { Fuel } \\
\text { Production }\end{array}$ & $\begin{array}{c}\text { Vehicle } \\
\text { Operation }\end{array}$ & Life-Cycle \\
\hline NG (kgce) & -52.33 & -3.53 & $42,096.57$ & $306,381.71$ & $348,422.41$ \\
Crude oil (kgce) & -205.53 & -0.34 & $-252,950.12$ & $-219,843.69$ & $-472,999.68$ \\
Coal (kgce) & 1744.40 & -103.37 & $-15,279.37$ & 0 & $-13,638.34$ \\
Total energy (kgce) & 1486.54 & -107.24 & $-226,132.93$ & $86,538.02$ & $-138,215.61$ \\
\hline
\end{tabular}

\subsubsection{Air Emission}

As shown in Figure 4 and Table 6, the LNG tractor-trailer emits $1860.07 \mathrm{~kg}$ less $\mathrm{NO}_{\mathrm{x}}$, $423.95 \mathrm{~kg}$ less $\mathrm{SO}_{x}, 61.00 \mathrm{~kg} \mathrm{PM}$, and $15.10 \mathrm{~kg}$ less NMVOC, but 2.72 tons more $\mathrm{CO}_{2}, 542.93 \mathrm{~kg}$ more $\mathrm{CO}$, and $2456.05 \mathrm{~kg}$ more $\mathrm{CH}_{4}$ than its diesel counterpart during the whole life-cycle. 


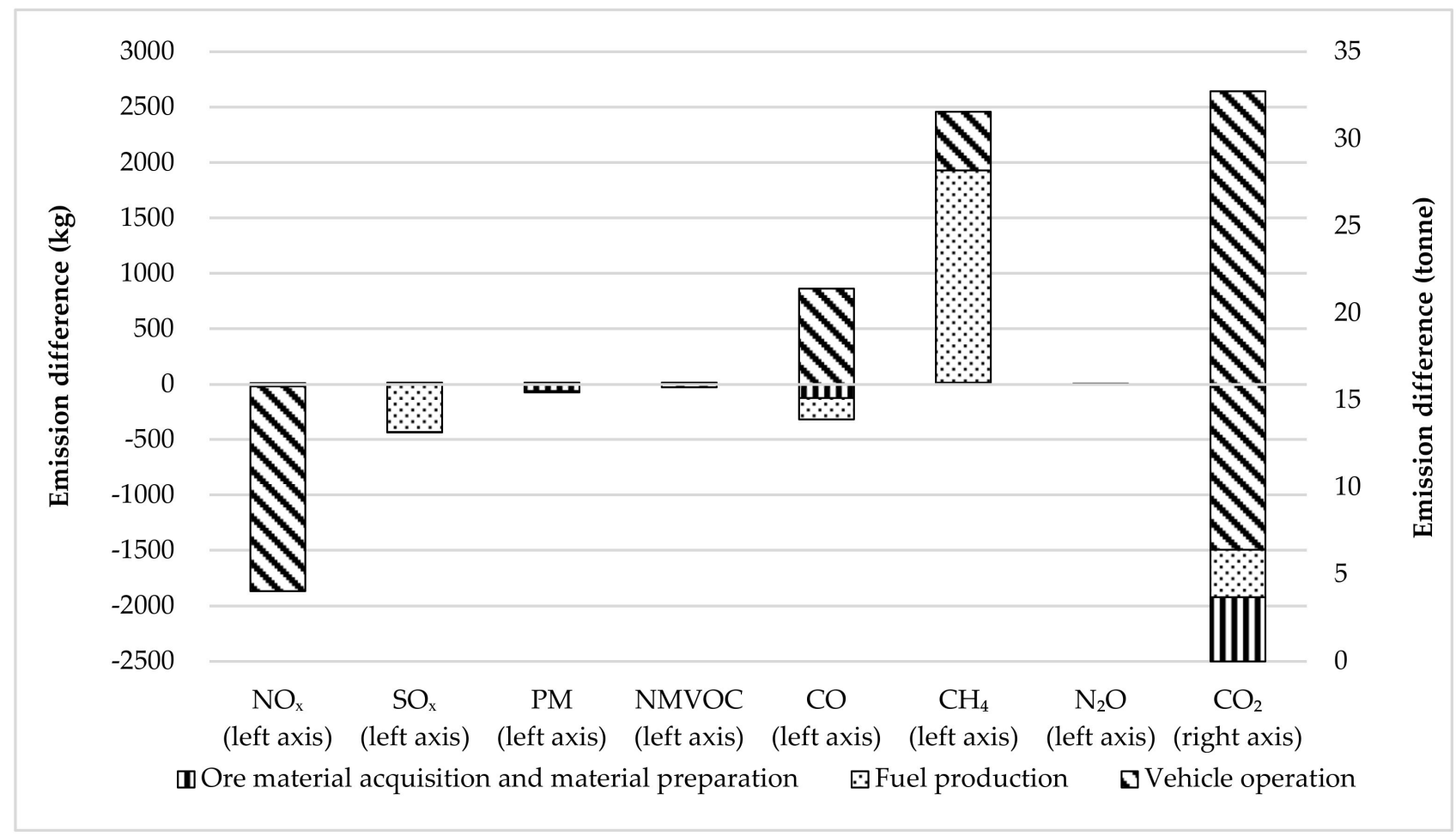

Figure 4. Air emissions of LNG compared to diesel tractor-trailer and contribution of different stages to the emission differences.

Table 6. Air emissions of LNG tractor-trailer compared to diesel tractor-trailer.

\begin{tabular}{ccccc}
\hline Processes & $\begin{array}{c}\text { Ore Material Acquisition and } \\
\text { Material Preparation }\end{array}$ & Fuel Production & Vehicle Operation & Life-Cycle \\
Difference & 8.77 & -21.9 & -1846.94 & -1860.07 \\
$\mathrm{NO}_{\mathrm{x}}(\mathrm{kg})$ & 12.55 & -433.48 & -3.02 & -423.95 \\
$\mathrm{SO}(\mathrm{kg})$ & -63.02 & 14.55 & -12.53 & -61 \\
$\mathrm{PM}(\mathrm{kg})$ & 0.06 & 15.26 & -30.42 & -15.1 \\
$\mathrm{NMVC}(\mathrm{kg})$ & -126.98 & -192.33 & 862.25 & 542.93 \\
$\mathrm{CO}(\mathrm{kg})$ & -0.01 & 0.01 & 0 & 2456.05 \\
$\mathrm{~N}_{2} \mathrm{O}(\mathrm{kg})$ & 15.17 & 1914.66 & 526.22 & 32.72 \\
$\mathrm{CH}_{4}(\mathrm{~kg})$ & 3.68 & 2.72 & 26.32 & \\
$\mathrm{CO}_{2}(\mathrm{t})$ & & & & \\
\hline
\end{tabular}

The ore material acquisition and material preparation stage, fuel production stage, and vehicle operation stage predominantly contribute to the lower life-cycle PM emissions $(69.95 \%), \mathrm{SO}_{\mathrm{x}}$ emissions (96.53\%), and $\mathrm{NO}_{\mathrm{x}}$ and $\mathrm{NMVOC}$ emissions $(98.37 \%$ and $66.51 \%)$, respectively. The PM emission during ore material acquisition and material preparation for the LNG cylinder and its bracket is $63.02 \mathrm{~kg}$ lower than that for the diesel tank and its bracket; the $\mathrm{SO}_{x}$ emission during fuel production for the LNG tractor-trailer is $433.48 \mathrm{~kg}$ lower than that for its diesel counterpart; and the $\mathrm{NO}_{\mathrm{x}}$ and NMVOC emission during operation of the LNG tractor-trailer is, respectively, $1846.94 \mathrm{~kg}$ and $30.42 \mathrm{~kg}$ lower than that during the operation of its diesel counterpart. The lower life-cycle PM emission of the LNG tractor-trailer is primarily attributable to its lower aluminum consumption and the fact that acquiring and preparing aluminum has a 38.78 times higher PM emission intensity than acquiring and preparing steel (see Table A2), which results in its much lower PM emission during ore material acquisition and material preparation. The lower life-cycle $\mathrm{SO}_{x}$ emissions of the LNG tractor-trailer can be largely attributed to the far lower coal consumption for producing LNG (see Table A2), which leads to much lower $\mathrm{SO}_{\mathrm{x}}$ emissions during $\mathrm{LNG}$ production. The lower life-cycle $\mathrm{NO}_{\mathrm{x}}$ emissions are mainly because operating the LNG tractor-trailer has a $\mathrm{NO}_{\mathrm{x}}$ emission intensity $81.14 \%$ lower than 
its diesel counterpart (see Table A2). The lower life-cycle NMVOC emissions of the LNG tractor-trailer are mainly because of its much lower NMVOC emissions during operation.

The fuel production stage and vehicle operation stage contribute most to the higher life-cycle $\mathrm{CH}_{4}$ emission (77.96\%) and $\mathrm{CO}$ and $\mathrm{CO}_{2}$ emissions (72.98\% and $80.43 \%$ ), respectively. The $\mathrm{CH}_{4}$ emission during fuel production for the LNG tractor-trailer is $1914.66 \mathrm{~kg}$ higher than that for its diesel counterpart, while $\mathrm{CO}$ and $\mathrm{CO}_{2}$ emissions during operation of the LNG tractor-trailer are $862.25 \mathrm{~kg}$ and $26.32 \mathrm{t}$ higher than that during the operation of its diesel counterpart, respectively. The higher life-cycle $\mathrm{CH}_{4}$ emissions can be mainly attributed to the fact that producing LNG has a higher $\mathrm{CH}_{4}$ emission intensity than producing diesel as well as the higher fuel consumption rate of the LNG tractor-trailer, which leads to higher $\mathrm{CH}_{4}$ emissions during fuel production (see Table A2). The higher life-cycle $\mathrm{CO}$ emission is caused by the incomplete combustion of LNG and the higher fuel consumption rate of the LNG tractor-trailer, which brings about more $\mathrm{CO}$ emission during the operation of the LNG tractor-trailer. The higher life-cycle $\mathrm{CO}_{2}$ emissions are primarily driven by the higher fuel consumption rate of the LNG tractor-trailer, which generates more $\mathrm{CO}_{2}$ emissions during the operation of the LNG tractor-trailer, although the $\mathrm{CO}_{2}$ emission factor for LNG combustion is only $75.71 \%$ of that for diesel combustion (Table A2).

\subsection{LCIA Results}

As shown in Figure 5 and Table 7, the LNG tractor-trailer has $337.92 \mathrm{~kg}$ antimony eq., $1438.78 \mathrm{~kg} \mathrm{SO}_{2}$ eq., and $2689.09 \mathrm{~kg}$ 1,4-dichlorobenzene eq. lower ADP, AP, and HTP impacts, respectively, but 101.49 t CO 2 eq. and $6.78 \mathrm{~kg} \mathrm{C}_{2} \mathrm{H}_{4}$ eq. higher GWP and POCP impacts, respectively, than those of the diesel tractor-trailer during the whole life cycle.

Table 7. Environmental impacts of LNG tractor-trailer compared to diesel tractor-trailer.

\begin{tabular}{|c|c|c|c|c|c|c|c|}
\hline Difference & Process & $\begin{array}{l}\text { Ore material Acquisition } \\
\text { and Material Preparation }\end{array}$ & $\begin{array}{c}\text { Accessory } \\
\text { Manufacturing }\end{array}$ & $\begin{array}{c}\text { Fuel } \\
\text { Production }\end{array}$ & $\begin{array}{c}\text { Vehicle } \\
\text { Operation }\end{array}$ & Recycling & Life-Cycle \\
\hline \multirow{6}{*}{$\begin{array}{c}\mathrm{ADP}(\mathrm{kg} \\
\text { antimony eq.) }\end{array}$} & Coal & 0.00 & 0.00 & -0.01 & 0.00 & - & -0.01 \\
\hline & NG & 0.00 & 0.00 & 0.04 & 0.30 & - & 0.34 \\
\hline & Crude oil & -0.15 & 0.00 & -180.89 & -157.22 & - & -338.26 \\
\hline & Iron ore & 0.36 & - & - & - & -0.33 & 0.03 \\
\hline & $\begin{array}{c}\text { Aluminum } \\
\text { ore }\end{array}$ & -0.09 & - & - & - & 0.07 & -0.02 \\
\hline & Sum & 0.12 & - & -180.86 & -156.92 & -0.26 & -337.92 \\
\hline \multirow{3}{*}{$\mathrm{AP}\left(\mathrm{kg} \mathrm{SO}_{2}\right.$ eq.) } & $\mathrm{SO}_{\mathrm{x}}$ & 15.06 & - & -520.17 & -3.63 & - & -508.74 \\
\hline & $\mathrm{NO}_{\mathrm{x}}$ & 4.39 & - & -10.95 & -923.47 & - & -930.03 \\
\hline & Sum & 19.44 & - & -531.12 & -927.10 & - & -1438.78 \\
\hline \multirow{4}{*}{$\begin{array}{l}\mathrm{GWP}(\mathrm{t} \\
\mathrm{CO}_{2} \text { eq.) }\end{array}$} & $\mathrm{CO}_{2}$ & 3.68 & - & 2.72 & 26.32 & - & 32.72 \\
\hline & $\mathrm{N}_{2} \mathrm{O}$ & 0.00 & & 0.00 & 0.00 & - & 0.00 \\
\hline & $\mathrm{CH}_{4}$ & 0.42 & - & 53.61 & 14.73 & - & 68.76 \\
\hline & Sum & 4.11 & - & 56.33 & 41.05 & - & 101.49 \\
\hline \multirow{5}{*}{$\begin{array}{l}\text { POCP (kg } \\
\mathrm{C}_{2} \mathrm{H}_{4} \text { eq.) }\end{array}$} & $\mathrm{CO}$ & -3.43 & - & -5.19 & 23.28 & - & 14.66 \\
\hline & NMVOC & 0.01 & - & 2.29 & -4.56 & - & -2.26 \\
\hline & $\mathrm{CH}_{4}$ & 0.09 & - & 11.49 & 3.16 & - & 14.74 \\
\hline & $\mathrm{SO}_{\mathrm{x}}$ & 0.60 & - & -20.81 & -0.15 & - & -20.36 \\
\hline & Sum & -2.73 & - & -12.22 & 21.73 & - & 6.78 \\
\hline \multirow{4}{*}{$\begin{array}{l}\text { HTP (kg 1,4- } \\
\text { dichlorobenzene eq.) }\end{array}$} & $\mathrm{SO}_{\mathrm{x}}$ & 12.05 & - & -416.14 & -2.90 & - & -406.99 \\
\hline & $\mathrm{NO}_{\mathrm{x}}$ & 10.53 & - & -26.28 & -2216.32 & - & -2232.07 \\
\hline & $\mathrm{PM}$ & -51.68 & - & 11.93 & -10.27 & - & -50.02 \\
\hline & Sum & -29.11 & - & -430.49 & -2229.50 & - & -2689.09 \\
\hline
\end{tabular}




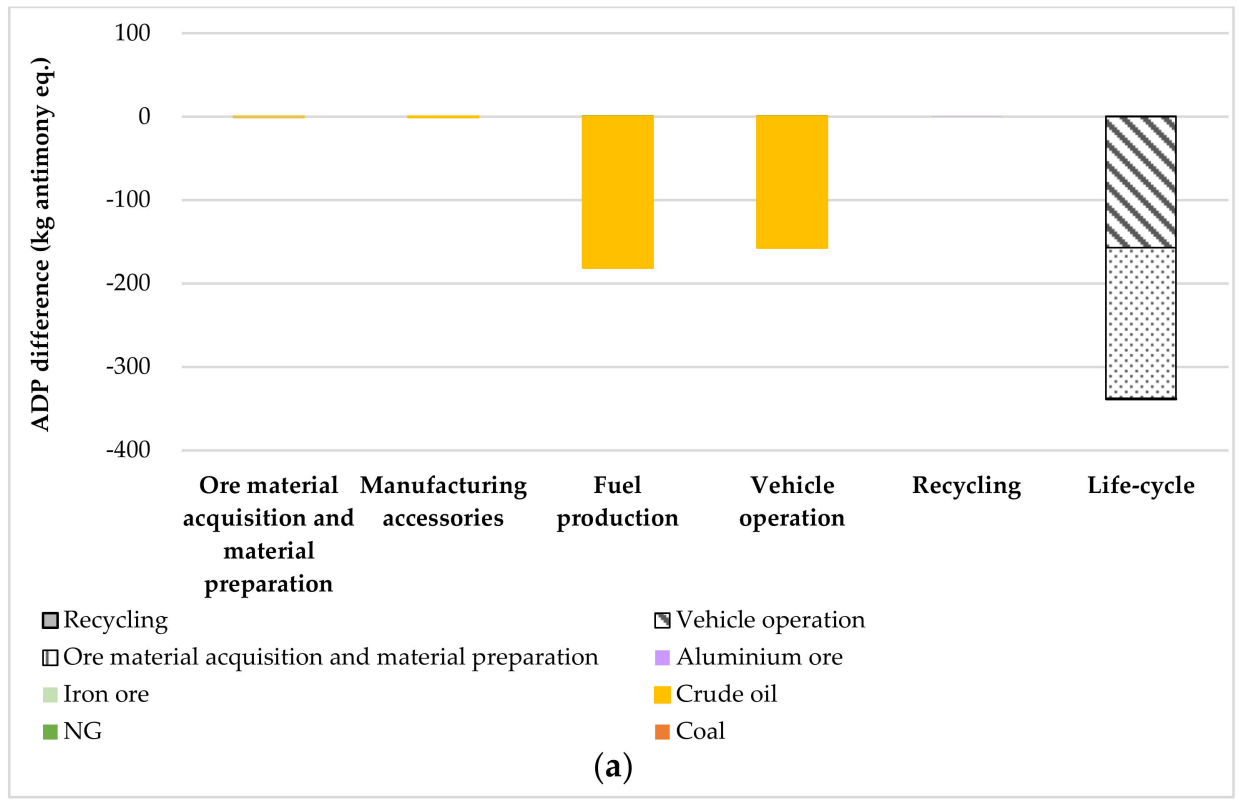

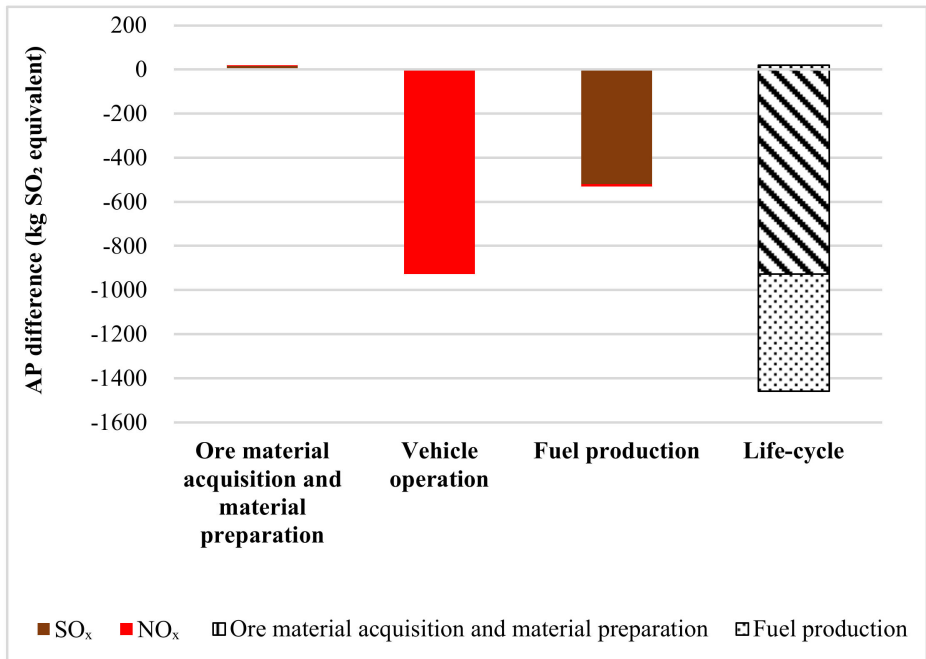

(b)

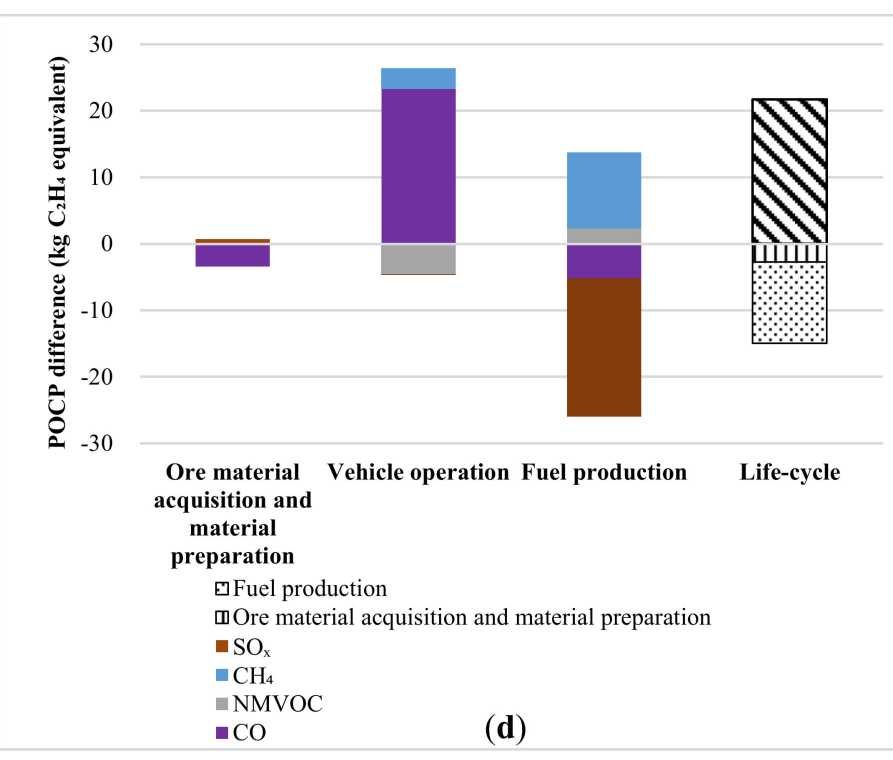

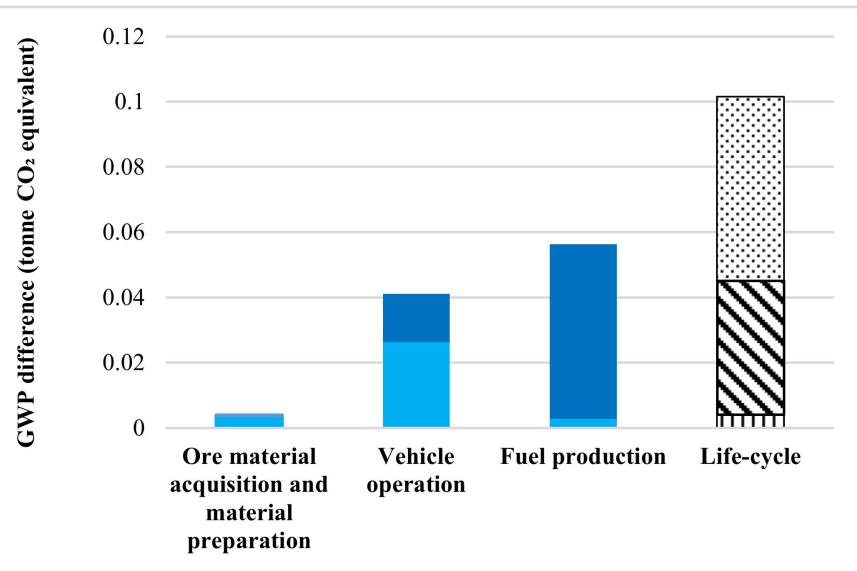

๑5uel production $\square$ Ore material acquisition and material preparation $\square \mathrm{CH}_{4} \quad \square \mathrm{CO}_{2}$

(c)

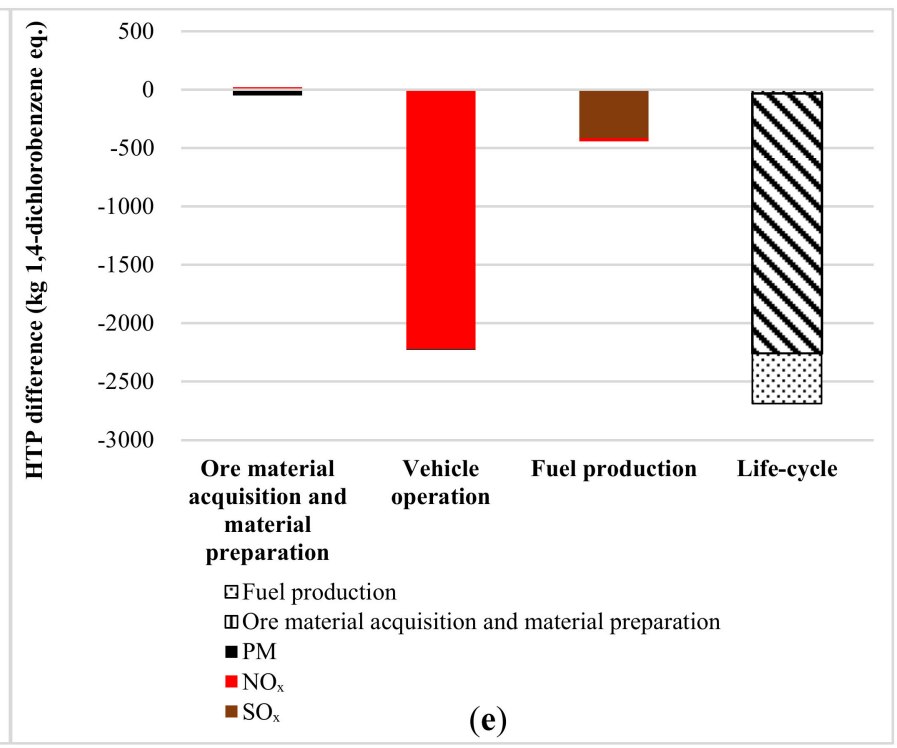

Figure 5. Environmental impacts of LNG tractor-trailer compared to diesel tractor-trailer: (a) abiotic depletion potential (ADP); (b) acidification potential (AP); (c) global warming potential (GWP); (d) photooxidant creation potential (POCP); (e) human toxicity potential (HTP). 
Fuel production and vehicle operation were found to be the main stages contributing to the life-cycle ADP difference (accounting for $53.48 \%$ and $46.40 \%$ of the whole life cycle, respectively) and GWP difference (accounting for $55.51 \%$ and $40.45 \%$ of the whole life cycle, respectively). The lower ADP of the LNG tractor-trailer is mainly because of the much lower ADP factor of NG than crude oil and much lower oil consumption for producing LNG and operating the LNG tractor-trailer. The higher GWP impact of the LNG tractortrailer is mainly caused by its higher $\mathrm{CH}_{4}$ emissions during fuel production and higher $\mathrm{CO}_{2}$ emissions during operation.

Vehicle operation was found to be the most critical stage contributing to the difference in life-cycle AP, HTP and POCP impact, accounting for $62.74 \%, 82.91 \%$, and $59.24 \%$, respectively. The lower AP and HTP impact of the LNG tractor-trailer is mainly because of its lower $\mathrm{NO}_{x}$ emissions during vehicle operation, while the higher POCP impact is mainly attributed to its higher $\mathrm{CO}$ emissions during operation.

\subsection{Sensitivity Analysis Results}

Figure 6 shows how the reduction in fuel (LNG or diesel) consumption rate affects the differences in the five categories of impacts.

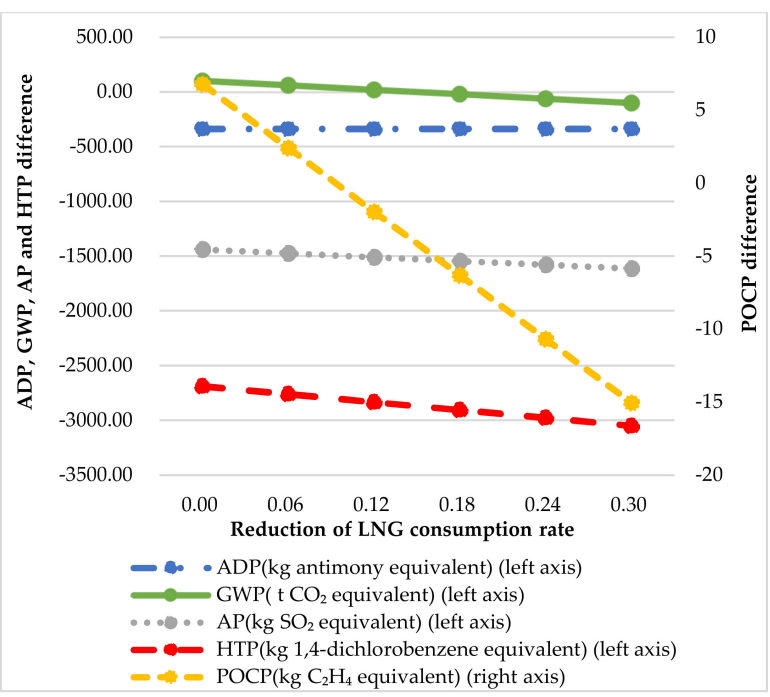

(a)

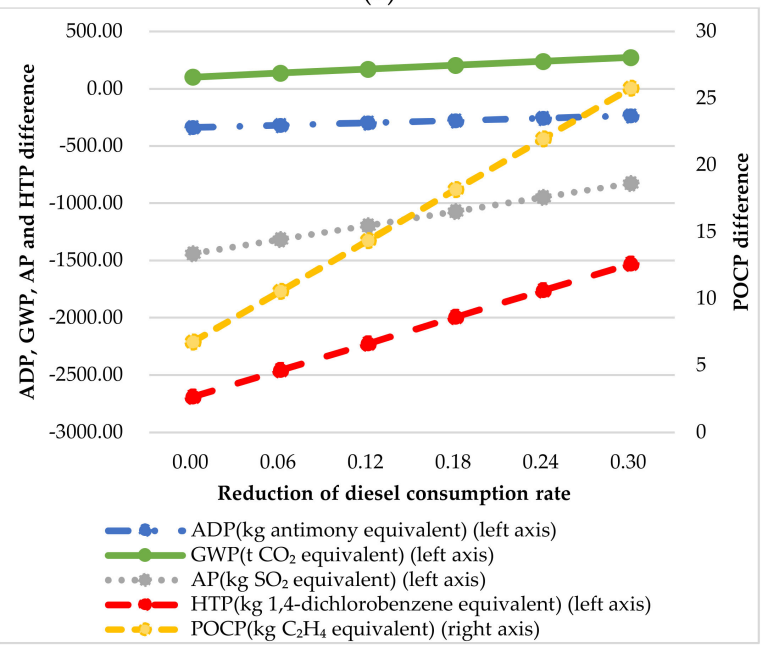

(b)

Figure 6. The impact of the fuel consumption rate on the differences in five categories of environmental impacts: (a) reduction of LNG consumption rate; (b) reduction of diesel consumption rate. 
The reduction of $30 \%$ in the LNG consumption rate leads to $199.37 \%$ and $322.06 \%$ decreases in the GWP and POCP differences and $0.23 \%, 12.21 \%$, and $13.45 \%$ increases in the ADP, AP and HTP differences, respectively. The results indicate that the POCP and GWP differences are significantly sensitive to the LNG consumption rate. Conversely, the AP difference and HTP differences are not very sensitive to the LNG consumption rate, and the ADP difference is insensitive to it. This implies that the improvement of LNG engine efficiency would greatly change the comparison results related to photochemical smog pollution and climate change. However, it does not significantly influence acid rain corrosion and human damage and has almost no influence on resource depletion.

Conversely, the reduction of $30 \%$ in the diesel consumption rate raises the GWP and POCP differences by $170.58 \%$ and $280.00 \%$ and decreases the ADP, AP, and HTP differences by $30.22 \%, 42.61 \%$, and $43.12 \%$, respectively. The results suggest that the POCP and GWP differences are more significantly sensitive to the diesel consumption rate, followed by the HTP difference and AP difference, while the ADP difference is least sensitive to the diesel consumption rate. This implies that the improvement of diesel engine efficiency would more significantly change the comparison results related to photochemical smog pollution and climate change, followed by health damage and acid rain corrosion, but would not have much influence on resource depletion.

Moreover, the sensitivity of the GWP and POCP differences to the LNG consumption rate is more distinguished than that to the diesel consumption rate, but the sensitivity of $\mathrm{ADP}, \mathrm{AP}$, and HTP differences to the LNG consumption rate is less distinguished than that to the diesel consumption rate. This suggests that under the same technology development trend of LNG engines and diesel engines, substituting diesel tractor-trailer with LNG tractor-trailer may have greater potential in mitigating photochemical smog pollution and global warming but less potential in saving resources and preventing acid rain corrosion and health damage.

\section{Conclusions}

With the aim of comparing the environmental performance of LNG tractor-trailer and its diesel counterpart in China comprehensively over the whole life-cycle, we developed a bottom-up calculation model for environmental loads differences between the two alternatives, which covers the ore resource acquisition, material preparation, accessory manufacturing, and vehicle operation and recycling stages. Based on this model, we performed a comprehensive comparative analysis of an LNG tractor-trailer and its diesel counterpart in terms of material consumption, energy consumption, and air emissions by a life-cycle inventory database specific to China. Furthermore, we evaluated the difference between the two alternatives in five categories of environmental impacts using CML 2001 model and investigated the influences of engine technology levels on the these impacts in the sensitivity analysis.

The LCI results of this study imply that replacing the diesel tractor-trailer with the LNG tractor-trailer would reduce aluminum ore consumption, energy consumption, and $\mathrm{SO}_{\mathrm{x}}$, $\mathrm{NO}_{x}, \mathrm{PM}$, and NMVOC emissions but increase iron ore consumption and $\mathrm{CO}_{2}, \mathrm{CO}$, and $\mathrm{CH}_{4}$ emissions from a life-cycle perspective. These results partly contradict the perception that LNG vehicles "reduce emissions". Moreover, almost no $\mathrm{SO}_{\mathrm{x}}$ and $\mathrm{PM}$ emissions during LNG combustion is a commonly stated benefit of LNG vehicles over diesel due to the hydrodealkylation, dehydration, and deacidification of LNG. Interestingly, the results of our case study show that instead of the vehicle operation stage, the fuel production stage and ore material acquisition and material preparation stage make a significant contribution to the lower life-cycle $\mathrm{SO}_{x}$ and PM emissions of the LNG tractor-trailer, respectively. It is therefore important to compare the environmental loads of LNG tractor-trailers and their diesel counterparts throughout the whole life-cycle stages, not only the operation stage.

Government statistics show that heavy-duty diesel trucks in China emitted 4,299,000 tons of $\mathrm{NO}_{\mathrm{x}}$ and 360,000 tons of $\mathrm{PM}$ during operation in 2019, accounting for $69.07 \%$ and $52.2 \%$ of the total $\mathrm{NO}_{\mathrm{x}}$ and $\mathrm{PM}$ emissions of in-use vehicles and $34.84 \%$ and $0.33 \%$ of the national 
emissions of $\mathrm{NO}_{x}$ and $\mathrm{PM}$ in exhaust gas, respectively (Ministry of Ecology and Environment of China, 2020a, 2020b). The LCI results of our study suggest that from a life-cycle perspective, switching diesel HDV to LNG HDV would help meet the national $\mathrm{NO}_{\mathrm{x}}$ and PM reduction target.

Although our case study shows that poor fuel economy is the main cause of the higher life-cycle $\mathrm{CO}_{2}$ emissions of the LNG tractor-trailer, it would have comparable lifecycle $\mathrm{CO}_{2}$ emissions with diesel if its fuel consumption rate could be reduced by $5.42 \%$ $(5.42 \mathrm{~L} / 100 \mathrm{~km})$ in the case of the unchanged fuel economy of its diesel counterpart. A transition to the LNG tractor-trailer could generate a reduction of up to $52.73 \%$ if the LNG tractor-trailer attains a parity fuel consumption rate with diesel.

The LCIA results indicate that replacing the diesel tractor-trailer with LNG would alleviate resource depletion, acid rain pollution, and health damage but accelerate climate change and photochemical smog pollution from a life-cycle perspective. Interestingly, the LNG tractor-trailer is superior to diesel in terms of resource depletion despite its higher energy consumption (in coal equivalent) during operation. This is mainly because crude oil is much scarcer than natural gas in China, which is reflected in the ADP factor of crude oil and natural gas. This implies that replacing the diesel tractor-trailer with LNG would be greatly favorable for China's energy security even though the fuel economy of the LNG tractor-trailer were much worse than that of its diesel counterpart.

The LCIA results also show that fuel production and vehicle operation are the most critical stages that contribute to the differences in life-cycle environmental impacts between the two alternatives. In other words, the accessory difference between the LNG tractor-trailer and its diesel counterpart has little influence on the LCIA results, while the difference in their fuel consumption predominantly contributes to the LCIA results. The high fuel-consumption rate of the LNG tractor-trailer results in more $\mathrm{CO}_{2}$ and $\mathrm{CO}$ emissions during its operation, which are the main contributors to its higher GWP and POCP impact, respectively. Furthermore, the sensitivity analysis results indicate that if manufacturers can improve the relative efficiency of LNG engines, the LNG tractor-trailer would have better performance when impacted by global warming and photochemical smog pollution. The results of our study imply that the LNG tractor-trailer would have comparable life-cycle GWP and POCP impacts if its fuel consumption rate could be reduced by approximately $15.04 \%(15.04 \mathrm{~L} / 100 \mathrm{~km})$ and $9.31 \%(9.31 \mathrm{~L} / 100 \mathrm{~km})$, respectively, in the case of an unchanged fuel economy of its diesel counterpart. A reduction in GWP and POCP impact of up to $44.60 \%$ and $49.23 \%$, respectively, is viable if the LNG tractor-trailer attains a parity fuel consumption rate with diesel.

However, there are currently no policies in China that encourage improvements in LNG engine efficiency. Instead, the innovation of LNG engine technology may be held back by the existing Refined Oil Excise Tax. It applies to diesel at a tax rate of CNY 1.2 per liter but excludes LNG [46]. This tax differential is considered to allow lower-efficiency LNG engines to be competitive with diesel because it one-sidedly subsidizes the cost of an LNG vehicle relative to diesel. In addition, the fuel consumption rate of diesel HDVs is required to be published, but this is not mandatory for LNG HDVs in China. Not Requiring this for LNG HDVs would also limit further development of LNG HDV engines by manufacturers. Therefore, policymakers should modify the existing fuel tax policy to better reflect the external costs associated with the current technology of LNG engines. It is also suggested to adopt policies that incentivize manufacturers to improve LNG engine efficiency, such as stricter fuel economy standards on LNG HDVs and subsidies for the advanced technology of LNG engines.

Author Contributions: Conceptualization, S.H. and H.C.; methodology, S.H. and H.C.; software, S.H. and H.C.; validation, S.H. and H.C.; formal analysis, S.H.; investigation, H.C.; resources, S.H.; data curation, S.H.; writing — original draft preparation, S.H. and H.C.; writing-review and editing, S.H.; visualization, S.H. and H.C.; supervision, S.H.; project administration, S.H.; funding acquisition, S.H. All authors have read and agreed to the published version of the manuscript. 
Funding: This research was funded by Strategic Priority Research Program of the Chinese Academy of Sciences, grant number XDA19040102; the National Natural Science Foundation of China for Young Scholars, grant number 41901249; National Key Research and Development Program of China, grant number 2016YFA0602802; and National Natural Science Foundation of China, grant number 71173072.

Institutional Review Board Statement: Not applicable.

Informed Consent Statement: Not applicable.

Data Availability Statement: Not applicable.

Acknowledgments: We would like to thank Director Peipei Chao of China Automotive Engineering Research Institute Co., Ltd. and Chairman Hanru Liu of Hualing Xingma Automobile (Group) Co. Ltd. for kindly providing opportunities to collect data on LNG tractor-trailer in China.

Conflicts of Interest: The authors declare no conflict of interest.

\section{Appendix A}

Table A1. Main technical and performance parameters of the CAMC tractor-trailer functional unit used in this study.

\begin{tabular}{ccc}
\hline Vehicle & Diesel Tractor-Trailer & LNG Tractor-Trailer \\
\hline Boundary dimensions & & \\
Length $\times$ width $\times$ height & $7085 \times 2550 \times 3800$ & $7490 \times 2550 \times 3800$ \\
$(\mathrm{~mm} \times \mathrm{mm} \times \mathrm{mm})$ & & \\
\hline Tractive weight $(\mathrm{t})$ & 40 & $3000+1350$ \\
Wheelbase $(\mathrm{mm})$ & $3400+1350$ & 9680 \\
Curb weight $(\mathrm{kg})$ & 8700 & 1000 \\
Volume of feed system $(\mathrm{L})$ & 800 & 316 \\
Rated power $(\mathrm{kW})$ & 327 & 100 \\
\hline
\end{tabular}

Table A2. Specific inventory data for different life-cycle stages.

\begin{tabular}{|c|c|c|c|}
\hline Life-Cycle Stage & Data Types & Val & \\
\hline \multirow{16}{*}{$\begin{array}{l}\text { Ore material acquisition } \\
\text { and material preparation }\end{array}$} & \multirow{2}{*}{$\begin{array}{l}\text { Use ratios of materials during ore material acquisition and } \\
\text { material preparation }(\%){ }^{(\mathrm{i})}\end{array}$} & Steel & 32.77 \\
\hline & & Cast aluminum & 22.67 \\
\hline & \multirow{3}{*}{$\begin{array}{l}\text { Integrated energy intensity data for acquiring and preparing } \\
\text { steel (kg/kg for raw coal and crude oil, } \mathrm{kg} / \mathrm{m}^{3} \text { for natural gas) }\end{array}$} & Raw coal & 1.1548 \\
\hline & & Crude oil & 0.0094 \\
\hline & & Natural gas & 0.0046 \\
\hline & \multirow{8}{*}{$\begin{array}{l}\text { Integrated emission intensity data for acquiring and preparing } \\
\qquad \text { steel }(\mathrm{g} / \mathrm{kg})\end{array}$} & NMVOC & 0.0418 \\
\hline & & $\mathrm{SO}_{\mathrm{x}}$ & 9.5569 \\
\hline & & $\mathrm{NO}_{\mathrm{x}}$ & 4.4640 \\
\hline & & $\mathrm{CO}$ & 0.3230 \\
\hline & & PM & 9.4156 \\
\hline & & $\mathrm{CH}_{4}$ & 5.3481 \\
\hline & & $\mathrm{N}_{2} \mathrm{O}$ & 0.0062 \\
\hline & & $\mathrm{CO}_{2}$ & 2133.7190 \\
\hline & \multirow{3}{*}{$\begin{array}{l}\text { Integrated energy intensity data for acquiring and preparing } \\
\text { cast aluminum ( } \mathrm{kg} / \mathrm{kg} \text { for raw coal and crude oil, } \mathrm{kg} / \mathrm{m}^{3} \text { for } \\
\text { natural gas) }\end{array}$} & Raw coal & 5.8566 \\
\hline & & Crude oil & 0.6927 \\
\hline & & Natural gas & 0.2315 \\
\hline
\end{tabular}


Table A2. Cont.

\begin{tabular}{|c|c|c|c|}
\hline \multirow[t]{12}{*}{ Life-Cycle Stage } & \multirow[t]{2}{*}{ Data Types } & \multicolumn{2}{|l|}{ Value } \\
\hline & & NMVOC & 25.2767 \\
\hline & \multirow{7}{*}{$\begin{array}{l}\text { Integrated emission intensity data for acquiring and preparing } \\
\text { cast aluminum }(\mathrm{g} / \mathrm{kg})\end{array}$} & $\mathrm{SO}_{\mathrm{x}}$ & 78.6827 \\
\hline & & $\mathrm{NO}_{\mathrm{x}}$ & 25.2767 \\
\hline & & $\mathrm{CO}$ & 504.9787 \\
\hline & & PM & 374.7286 \\
\hline & & $\mathrm{CH}_{4}$ & 11.8997 \\
\hline & & $\mathrm{N}_{2} \mathrm{O}$ & 0.1420 \\
\hline & & $\mathrm{CO}_{2}$ & $14,098.6340$ \\
\hline & \multirow{3}{*}{$\begin{array}{l}\text { Conversion factors from physical unit to coal equivalent } \\
\text { (kgce/kg for raw coal and crude oil, } \mathrm{kgce} / \mathrm{m}^{3} \text { for natural gas) }\end{array}$} & Raw coal & 0.7143 \\
\hline & & Crude oil & 1.4286 \\
\hline & & Natural gas & $1.215^{\text {(ii) }}$ \\
\hline \multirow{4}{*}{$\begin{array}{l}\text { Accessory } \\
\text { manufacturing }\end{array}$} & \multirow{2}{*}{ Use ratios of materials during accessory manufacture (\%) } & Steel & 55 \\
\hline & & Cast aluminum & 80 \\
\hline & \multirow{2}{*}{$\begin{array}{l}\text { Amount of energy consumption for manufacturing fuel tank } \\
\text { and bracket (kgce) }\end{array}$} & LNG tractor-trailer & 149 \\
\hline & & Diesel tractor-trailer & 210 \\
\hline \multirow{2}{*}{ Recycling } & \multirow{2}{*}{ Recovery ratio of materials (\%) } & Steel & 93.3 \\
\hline & & Cast aluminum & 81.3 \\
\hline \multirow[t]{25}{*}{ Fuel production } & $\begin{array}{l}\text { Amount of energy consumption for producing a unit of LNG } \\
(\mathrm{kg} / \mathrm{kg} \text { for raw coal and crude oil, } \mathrm{kg} / \mathrm{m} \text { for natural gas })\end{array}$ & Raw coal & 2.4707 \\
\hline & & Crude oil & 10.3424 \\
\hline & & Natural gas & 179.3640 \\
\hline & \multirow{3}{*}{$\begin{array}{l}\text { Amount of energy consumption for producing a unit of LNG } \\
\qquad(\mathrm{Btu} / \mathrm{mmBtu})\end{array}$} & Raw coal & 2470.6820 \\
\hline & & Crude oil & $10,342.4188$ \\
\hline & & Natural gas & $179,363.9926$ \\
\hline & \multirow{8}{*}{$\begin{array}{l}\text { Amount of air emission for producing a unit of LNG } \\
\qquad(\mathrm{g} / \mathrm{kgce})\end{array}$} & NMVOC & 0.2157 \\
\hline & & $\mathrm{SO}_{\mathrm{x}}$ & 0.3618 \\
\hline & & $\mathrm{NO}_{\mathrm{x}}$ & 0.8039 \\
\hline & & $\mathrm{CO}$ & 0.5575 \\
\hline & & PM & 0.0530 \\
\hline & & $\mathrm{CH}_{4}$ & 6.5327 \\
\hline & & $\mathrm{N}_{2} \mathrm{O}$ & 0.0048 \\
\hline & & $\mathrm{CO}_{2}$ & 325.5496 \\
\hline & \multirow{3}{*}{$\begin{array}{l}\text { Amount of energy consumption for producing a unit of diesel } \\
\left(\mathrm{kg} / \mathrm{kg} \text { for raw coal and crude oil, } \mathrm{kg} / \mathrm{m}^{3} \text { for natural gas }\right)\end{array}$} & Raw coal & 0.1488 \\
\hline & & Crude oil & 1.1882 \\
\hline & & Natural gas & 0.0701 \\
\hline & \multirow{8}{*}{ Amount of air emission for producing a unit of diesel (g/kgce) } & NMVOC & 0.2312 \\
\hline & & $\mathrm{SO}_{\mathrm{x}}$ & 2.4746 \\
\hline & & $\mathrm{NO}_{\mathrm{x}}$ & 1.2199 \\
\hline & & $\mathrm{CO}$ & 1.6518 \\
\hline & & PM & 0.0077 \\
\hline & & $\mathrm{CH}_{4}$ & 0.3949 \\
\hline & & $\mathrm{N}_{2} \mathrm{O}$ & 0.0066 \\
\hline & & $\mathrm{CO}_{2}$ & 441.3109 \\
\hline \multirow{7}{*}{ Vehicle operation } & \multirow{2}{*}{ Fuel consumption rate (L/100 km) } & LNG tractor-trailer & 100 \\
\hline & & Diesel tractor-trailer & 44.8 \\
\hline & \multirow{5}{*}{$\begin{array}{l}\text { Amount of NMVOC, } \mathrm{NO}_{x}, \mathrm{CO}, \mathrm{PM} \text {, and } \mathrm{CH}_{4} \text { emission per unit } \\
\text { work for LNG engine operation }(\mathrm{g} /(\mathrm{kW} \cdot \mathrm{h}))\end{array}$} & NMVOC & 0 \\
\hline & & $\mathrm{NO}_{\mathrm{x}}$ & 0.2640 \\
\hline & & $\mathrm{CO}$ & 0.5610 \\
\hline & & PM & 0.0000 \\
\hline & & $\mathrm{CH}_{4}$ & 0.2110 \\
\hline
\end{tabular}


Table A2. Cont.

\begin{tabular}{|c|c|c|c|}
\hline \multirow[t]{2}{*}{ Life-Cycle Stage } & \multirow[t]{2}{*}{ Data Types } & \multicolumn{2}{|c|}{ Value } \\
\hline & & NMVOC & 0.0170 \\
\hline & \multirow{4}{*}{$\begin{array}{c}\text { Amount of } \mathrm{NMVOC}, \mathrm{NO}_{x}, \mathrm{CO}, \mathrm{PM} \text {, and } \mathrm{CH}_{4} \text { emission per unit } \\
\text { work for diesel engine operation }(\mathrm{g} /(\mathrm{kW} \cdot \mathrm{h}))\end{array}$} & $\mathrm{NO}_{\mathrm{x}}$ & 1.4000 \\
\hline & & $\mathrm{CO}$ & 0.3000 \\
\hline & & PM & 0.0070 \\
\hline & & $\mathrm{CH}_{4}$ & 0 \\
\hline & \multirow{2}{*}{ Sulfur in fuel (mg/kg) } & LNG & 0.0000 \\
\hline & & Diesel & 10 \\
\hline & \multirow{2}{*}{$\mathrm{CO}_{2}$ emission factor of fuel $(\mathrm{g} / \mathrm{MJ})$} & LNG & 56.10 \\
\hline & & Diesel & 74.10 \\
\hline & \multirow{2}{*}{$\begin{array}{l}\text { Conversion factor from physical unit to coal equivalent } \\
(\mathrm{kgce} / \mathrm{MJ} \text { for heat, } \mathrm{kgce} / \mathrm{kW} \cdot \mathrm{h} \text { for electricity })\end{array}$} & Heat & 0.03412 \\
\hline & & Electricity & 0.1229 \\
\hline & \multirow{2}{*}{ Calorific value (MJ/kg) } & LNG & $49.3381^{\text {(iii) }}$ \\
\hline & & Diesel & 42.652 \\
\hline & \multirow{2}{*}{ Density $(\mathrm{kg} / \mathrm{L})$} & LNG & $0.455^{\text {(iv) }}$ \\
\hline & & Diesel & 0.843 \\
\hline
\end{tabular}

Note: ${ }^{(i)}$ SinoCenter provides the weight of output material and input ore, so the use ratios of materials during ore material acquisition and material preparation were calculated as the ratio of output material to input ore. (ii) According to the China Energy Statistical Yearbook 2019, the conversion factor of the physical unit of natural gas to coal equivalent is $1.100 \sim 1.3300 \mathrm{kgce} / \mathrm{m}^{3}$, and this study used a median value between 1.100 and 1.3300 for calculation. (iii) The value was calculated as "Conversion factor from 1 million tonnes LNG to million tonnes oil equivalent (i.e., 1.169) $\div$ Conversion factor from 1 trillion British thermal units to million tonnes oil equivalent (i.e., 0.025) $\times$ Conversion factor from 1 British thermal unit to kilo joules (i.e., 1.055)", which was obtained from the "Approximate conversion factors" part of the BP Statistical Review of World Energy 2020. (iv) According to https:/ / www.unitrove.com/engineering/gas-technology/liquefied-natural-gas (15 October 2021), LNG has a density of approximately $0.43 \mathrm{~kg} / \mathrm{L}$ to $0.48 \mathrm{~kg} / \mathrm{L}$, and the median value of $0.455 \mathrm{~kg} / \mathrm{L}$ was taken as the LNG density in this study.

Table A3. Characterization factors of ADP, GWP 100, AP, HTP, and POCP.

\begin{tabular}{|c|c|c|c|}
\hline $\begin{array}{l}\text { Impact } \\
\text { Category }\end{array}$ & Contributor & Characterization Coefficient & Unit \\
\hline \multirow{5}{*}{ ADP } & Crude oil & $2.44 \times 10^{-5}$ & kg antimony eq./MJ \\
\hline & Natural gas & $3.34 \times 10^{-8}$ & kg antimony eq./MJ \\
\hline & Coal & $2.78 \times 10^{-8}$ & kg antimony eq./MJ \\
\hline & Iron & $1.05 \times 10^{-4}$ & $\mathrm{~kg}$ antimony eq. $/ \mathrm{kg}$ \\
\hline & Aluminum & $3.46 \times 10^{-4}$ & $\mathrm{~kg}$ antimony eq. $/ \mathrm{kg}$ \\
\hline \multirow{3}{*}{ GWP 100} & $\mathrm{CO}_{2}$ & $1.00 \times 10$ & $\mathrm{~kg} \mathrm{CO} 2$ eq. $/ \mathrm{kg}$ \\
\hline & $\mathrm{N}_{2} \mathrm{O}$ & $2.65 \times 10^{2}$ & $\mathrm{~kg} \mathrm{CO} 2$ eq. $/ \mathrm{kg}$ \\
\hline & $\mathrm{CH}_{4}$ & $2.80 \times 10^{1}$ & $\mathrm{~kg} \mathrm{CO} 2$ eq. $/ \mathrm{kg}$ \\
\hline \multirow[b]{2}{*}{$\mathrm{AP}$} & $\mathrm{SO}_{\mathrm{x}}$ & $1.20 \times 10$ & $\mathrm{~kg} \mathrm{SO}{ }_{2}$ eq. $/ \mathrm{kg}$ \\
\hline & $\mathrm{NO}_{\mathrm{x}}$ & $5.00 \times 10^{-1}$ & $\mathrm{~kg} \mathrm{SO} 2$ eq. $/ \mathrm{kg}$ \\
\hline \multirow{3}{*}{ HTP } & $\mathrm{SO}_{\mathrm{x}}$ & $9.6 \times 10^{-2}$ & $\begin{array}{c}\mathrm{kg} \text { 1,4-dichlorobenzene } \\
\text { eq. } / \mathrm{kg}\end{array}$ \\
\hline & $\mathrm{NO}_{\mathrm{x}}$ & $1.20 \times 10$ & $\begin{array}{c}\mathrm{kg} \text { 1,4-dichlorobenzene } \\
\text { eq. } / \mathrm{kg}\end{array}$ \\
\hline & PM & $8.20 \times 10^{-1}$ & $\begin{array}{c}\mathrm{kg} 1,4 \text {-dichlorobenzene } \\
\text { eq. } / \mathrm{kg}\end{array}$ \\
\hline \multirow{3}{*}{ POCP } & $\mathrm{SO}_{\mathrm{x}}$ & $4.80 \times 10^{-2}$ & $\mathrm{~kg} \mathrm{C}_{2} \mathrm{H}_{4}$ eq. $/ \mathrm{kg}$ \\
\hline & $\mathrm{CO}$ & $2.70 \times 10^{-2}$ & $\mathrm{~kg} \mathrm{C} \mathrm{H}_{4}$ eq. $/ \mathrm{kg}$ \\
\hline & NMVOC & $1.50 \times 10^{-1}$ & $\mathrm{~kg} \mathrm{C}_{2} \mathrm{H}_{4}$ eq. $/ \mathrm{kg}$ \\
\hline
\end{tabular}

Note: Due to data availability, the characterization factors for $\mathrm{SO}_{\mathrm{x}}$ and $\mathrm{PM}$ were represented by those for $\mathrm{SO}_{2}$ and PM10. 


\section{References}

1. Li, B.; Yin, H.; Wang, F. Will China's "dash for gas" halt in the future? Resour. Conserv. Recycl. 2018, 134, 303-312. [CrossRef]

2. Meyer, P.A.; Snowden-Swan, L.J.; Jones, S.B.; Rappe, K.G.; Hartley, D.S. The effect of feedstock composition on fast pyrolysis and upgrading to transportation fuels: Techno-economic analysis and greenhouse gas life cycle analysis. Fuel 2020, 259, 11. [CrossRef]

3. Shell Shell LNG outlook 2021. Available online: https://www.shell.com/energy-and-innovation/natural-gas/liquefied-naturalgas-lng/lng-outlook-2021.html (accessed on 1 November 2021).

4. Song, H.; Ou, X.; Yuan, J.; Yu, M.; Wang, C. Energy consumption and greenhouse gas emissions of diesel/LNG heavy-duty vehicle fleets in China based on a bottom-up model analysis. Energy 2017, 140, 966-978. [CrossRef]

5. Yuan, Z.; Ou, X.; Peng, T.; Yan, X. Life cycle greenhouse gas emissions of multi-pathways natural gas vehicles in china considering methane leakage. Appl. Energy 2019, 253, 113472. [CrossRef]

6. Luis Osorio-Tejada, J.; Llera-Sastresa, E.; Scarpellini, S. A multi-criteria sustainability assessment for biodiesel and liquefied natural gas as alternative fuels in transport systems. J. Nat. Gas Sci. Eng. 2017, 42, 169-186. [CrossRef]

7. Sharafian, A.; Blomerus, P.; Merida, W. Liquefied natural gas tanker truck-to-tank transfer for on-road transportation. Appl. Therm. Eng. 2019, 162, 15. [CrossRef]

8. Kung, L.; Butler, T.; Georges, G.; Boulouchos, K. How much energy does a car need on the road? Appl. Energy 2019, 256, 19. [CrossRef]

9. Khan, M.I.; Yasmin, T.; Shakoor, A. Technical overview of compressed natural gas (CNG) as a transportation fuel. Renew. Sustain. Energy Rev. 2015, 51, 785-797. [CrossRef]

10. Tong, F.; Jaramillo, P.; Azevedo, I.M.L. Comparison of Life Cycle Greenhouse Gases from Natural Gas Pathways for Light-Duty Vehicles. Energy Fuels 2015, 29, 6008-6018. [CrossRef]

11. Li, W.; Dai, Y.; Ma, L.; Hao, H.; Lu, H.; Albinson, R.; Li, Z. Oil-saving pathways until 2030 for road freight transportation in China based on a cost-optimization model. Energy 2015, 86, 369-384. [CrossRef]

12. National Bureau of Statistics of China. China Statistical Yearbook 2021; China Statistics Press: Beijing, China, 2020.

13. China Association of Automobile Manufacturers Ltd. China Automotive Industry Yearbook 2021; China Automobile Industry Editing and Publishing House: Tianjing, China, 2021.

14. Hao, H.; Wang, H.W.; Ouyang, M.G. Fuel consumption and life cycle GHG emissions by China's on-road trucks: Future trends through 2050 and evaluation of mitigation measures. Energy Policy 2012, 43, 244-251. [CrossRef]

15. Yang, Y.; Ji, D.S.; Sun, J.; Wang, Y.H.; Yao, D.; Zhao, S.; Yu, X.N.; Zeng, L.M.; Zhang, R.J.; Zhang, H.; et al. Ambient volatile organic compounds in a suburban site between Beijing and Tianjin: Concentration levels, source apportionment and health risk assessment. Sci. Total Environ. 2019, 695, 13. [CrossRef]

16. Zhou, J.B.; Guo, Y.J.; Huang, Z.W.; Wang, C. A review and prospects of gas mixture containing hydrogen as vehicle fuel in China. Int. J. Hydrogen Energy 2019, 44, 29776-29784. [CrossRef]

17. Held, M.; Schuecking, M. Utilization effects on battery electric vehicle life-cycle assessment: A case-driven analysis of two commercial mobility applications. Transp. Res. Part D Transp. Environ. 2019, 75, 87-105. [CrossRef]

18. Lee, D.-Y.; Elgowainy, A.; Kotz, A.; Vijayagopal, R.; Marcinkoski, J. Life-cycle implications of hydrogen fuel cell electric vehicle technology for medium- and heavy-duty trucks. J. Power Source 2018, 393, 217-229. [CrossRef]

19. Hernandez, M.; Messagie, M.; De Gennaro, M.; Van Mierlo, J. Resource depletion in an electric vehicle powertrain using different LCA impact methods. Resour. Conserv. Recycl. 2017, 120, 119-130. [CrossRef]

20. Yu, A.; Wei, Y.; Chen, W.; Peng, N.; Peng, L. Life cycle environmental impacts and carbon emissions: A case study of electric and gasoline vehicles in China. Transp. Res. Part D Transp. Environ. 2018, 65, 409-420. [CrossRef]

21. Petrauskienè, K.; Skvarnavičiūtè, M.; Dvarionienè, J. Comparative environmental life cycle assessment of electric and conventional vehicles in Lithuania. J. Clean. Prod. 2019, 246, 119042. [CrossRef]

22. Bicer, Y.; Dincer, I. Life cycle environmental impact assessments and comparisons of alternative fuels for clean vehicles. Resour. Conserv. Recycl. 2018, 132, 141-157. [CrossRef]

23. Cooper, J.; Hawkes, A.; Balcombe, P. Life cycle environmental impacts of natural gas drivetrains used in UK road freighting and impacts to UK emission targets. Sci. Total Environ. 2019, 674, 482-493. [CrossRef]

24. Tu, X.; Xu, J.; Chen, Y.; Yang, Y. An evaluation of differences between LNG and diesel commercial vehicle's life cycle energy consumption. China Mech. Eng. 2013, 24, 3211-3215. [CrossRef]

25. Tu, X.; Yang, Y.; Xu, J.; Chen, Y. Evaluation of Difference between LNG and Diesel Heavy-duty Commercial Vehicle's Life Cycle Environmental Emission. China Mech. Eng. 2013, 24, 1525-1530. [CrossRef]

26. Arteconi, A.; Brandoni, C.; Evangelista, D.; Polonara, F. Life-cycle greenhouse gas analysis of LNG as a heavy vehicle fuel in Europe. Appl. Energy 2010, 87, 2005-2013. [CrossRef]

27. Tong, F.; Jaramillo, P.; Azevedo, I.M. Comparison of life cycle greenhouse gases from natural gas pathways for medium and heavy-duty vehicles. Environ. Sci. Technol. 2015, 49, 7123-7133. [CrossRef]

28. Cai, H.; Burnham, A.; Chen, R.; Wang, M. Wells to wheels: Environmental implications of natural gas as a transportation fuel. Energy Policy 2017, 109, 565-578. [CrossRef]

29. Ozbilen, A.; Dincer, I.; Hosseini, M. Comparative Life Cycle Environmental Impact Assessment of Natural Gas and Conventional Vehicles. In Exergetic, Energetic and Environmental Dimensions; Academic Press: Cambridge, MA, USA, 2018 ; pp. 913-934. 
30. Langshaw, L.; Ainalis, D.; Acha, S.; Shah, N.; Stettler, M.E.J. Environmental and economic analysis of liquefied natural gas (LNG) for heavy goods vehicles in the UK: A Well-to-Wheel and total cost of ownership evaluation. Energy Policy 2019, 137, 111161. [CrossRef]

31. Chen, Y.; Yang, Y.; Li, X.; Dong, H.; Bai, R. Life cycle resource consumption of automotive power seats. Int. J. Environ. Stud. 2014, 71, 449-462. [CrossRef]

32. National Engineering Laboratory of Industrial Big-Data Application Technology, SinoCenter 2.0; National Engineering Laboratory of Industrial Big-Data Application Technology: Beijing, China, 2019.

33. Argonne National Laboratory. The Greenhouse Gases, Regulated Emissions, and Energy Use in Transportation Model 2020 Available online: http:/ / greet.es.anl.gov/ (accessed on 21 June 2021).

34. Ministry of Environmental Protection. Technical Guidelines for Compiling Air Pollutant Emission Inventory of On-Road Vehicles (Trial); Ministry of Environmental Protection (MEP): Beijing, China, 2014.

35. WorldAutoSteel, UCSB Model 5. 2017. Available online: https://www.worldautosteel.org/downloads/ucsb-model-5/ (accessed on 24 November 2021).

36. National Bureau of Statistics of China. China Energy Statistical Yearbook 2019; China Statistics Press: Beijing, China, 2020.

37. Administration, S. Chinese National Standard for Automobile Diesel Fuels (GB 19147-2016); ChineseStandard: Singapore, 2016; Available online: https:/ / www.chinesestandard.net/PDF.aspx/GB19147-2016 (accessed on 24 November 2021).

38. IPCC. 2006 IPCC Guidelines for National Greenhouse Gas Inventories; IPCC: Geneva, Switzerland, 2007.

39. BP. BP Statistical Review of World Energy 2020; BP: London, UK, 2020.

40. Chen, Y.; Ding, Z.; Liu, J.; Ma, J. Life cycle assessment of end-of-life vehicle recycling in China: A comparative study of environmental burden and benefit. Int. J. Environ. Stud. 2019, 76, 1019-1040. [CrossRef]

41. Li, W.; Bai, H.; Yin, J.; Xu, H. Life cycle assessment of end-of-life vehicle recycling processes in China-Take Corolla taxis for example. J. Clean. Prod. 2016, 117, 176-187. [CrossRef]

42. Guinée, J. Operational Guide to the ISO Standards; Springer: Berlin, Germany, 2002.

43. Zhang, Y.; Feng, G.; Wang, Z. Updated Resource Depletion Characterization Factors for Life Cycle Assessment-Case Studies on Iron and Steel Production in China. Mater. Sci. Forum 2016, 847, 358-365. [CrossRef]

44. Oers, L.V. CML-IA Database, Characterisation and Normalisation Factors for Midpoint Impact Category Indicators (Version 4.5); Leiden University: Leiden, The Netherlands, 2015. Available online: http:/ /www.cml.leiden.edu/software/data-cmlia.html (accessed on 24 November 2021).

45. Leach, F.; Kalghatgi, G.; Stone, R.; Miles, P. The scope for improving the efficiency and environmental impact of internal combustion engines. Transp. Eng. 2020, 1, 100005. [CrossRef]

46. OECD. Taxing Energy Use 2019; OECD: Paris, France, 2019. 